\title{
SEDAS, RASOS Y DAMASCOS: \\ LIMA Y EL CIERRE DEL COMERCIO TRIANGULAR CON MÉXICO Y MANILA EN LA PRIMERA MITAD DEL SIGLO XVII*
}

\author{
SILK, SATIN, AND DAMASK: LIMA AND THE CLOSURE \\ OF TRIANGULAR TRADE WITH MEXICO AND \\ MANILA IN THE FIRST HALF OF THE 17TH CENTURY
}

\author{
Margarita Suárez \\ Pontificia Universidad Católica del Perú, Lima, Perú, msuarez@pucp.edu.pe
}

\begin{abstract}
Resumen. Durante el periodo virreinal, una serie de condiciones colocaron a Lima en una situación de privilegio a nivel comercial. La formación de grandes consorcios mercantiles en la primera mitad de siglo XVII se tradujo en el control de efectivo del mercado interior y en una situación preferencial en el manejo del comercio a larga distancia. Los llamados peruleros no sólo compraban en Sevilla, sino también circulaban por Vizcaya, Portugal, Génova, Milán así como por el Pacífico. El objetivo de este artículo será analizar cómo factores de índole comercial (la ofensiva perulera en el Atlántico y las saturaciones del mercado peruano) así como los roces derivados de la intervención de funcionarios y la intermediación mexicana, llevaron a los comerciantes de Lima a apoyar el cese del tráfico legal con el fin de monopolizar el comercio ilícito entre ambas regiones.
\end{abstract}

Palabras clave: Perú; México; Filipinas; comercio asiático; peruleros; virreyes; funcionarios; siglo XVII.

Abstract. During the colonial period, a series of conditions put Lima in a privileged trade position. The creation of large trade consortiums in the first half of the 17 th century brought about an effective control of the domestic market and a preferential status in the conduct of international trade. Lima merchants, known as peruleros, not only purchased goods from Seville; their trading networks stretched across Biscay, Portugal, Genoa, Milan, and the Pacific. This article aims to assess how trade factors, such as the perulero offensive in the Atlantic and the saturation of the Peruvian market, as well as the conflicts created by the intervention of officials and Mexico's intermediation, led the Lima merchants to support the cessation of legitimate trade with an aim to monopolize illegal business between both regions.

* Esta investigación forma parte del proyecto Negociando el Poder (código 70242.3010) que financia la Pontificia Universidad Católica del Perú a través de su Dirección de Gestión de la Investigación. Quiero agradecer a Carlos Pereyra, Augusto Espinoza y Alonso Celes Espinoza por el apoyo brindado para la realización de este artículo.

Am. Lat. Hist. Econ., año 22, núm. 2, mayo-agosto, 2015, pp. 101-134 
Key words: Peru; Mexico; Philippines; Asian trade; peruleros; viceroys; officials; $17^{\text {th }}$ Century.

Fecha de recepción: 6 de mayo de 2014. Fecha de aceptación: 30 de septiembre de 2014 .

\section{EL IMPERIO HISPÁNICO EN ASIA}

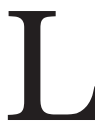

a conquista de las islas Filipinas por Miguel López de Legazpi en 1565 fue producto de las expectativas hispanas por ganar una presencia en Oriente que hiciera realidad el sueño de tener acceso a las especias. Pero nunca imaginaron que este anhelo sólo traería gastos y problemas. Las islas no tenían ni especias ni metales, a diferencia de las riquezas metálicas que encontraron abundantemente en América. Los territorios, además, se hallaban muy lejos de la península, y el espacio más cercano era México, que se hallaba a 6000 millas marinas (Alonso, 2009, p. 18). Para empeorar el escenario, el área en donde se encontraban las islas Filipinas estaba compuesta por territorios en conflicto. Cuando Legazpi llegó hubo de pelear contra corsarios y piratas chinos y japoneses, así como contra los "moros" asentados en Mindanao y Joló (Barrantes, 2004, pp. 21 y ss.; García, 1996, pp. 34 y ss.). Portugueses, castellanos y chinos se disputaban el control comercial de los bienes que procedían de China, Japón, la India portuguesa, las islas Molucas e Indochina. Asimismo, el Tratado de Tordesillas no contemplaba la creación de otra línea divisoria distinta de la atlántica, por lo que las islas Molucas se convirtieron en el punto oriental de disputa del tratado entre españoles y portugueses (Subrahmanyam, 2005, p. 715). De esa manera, inicialmente la presencia española sólo contempló la creación de un puesto militar que exigiese a sus adversarios ingleses y holandeses sufragaran grandes gastos militares que, a la larga, impidiesen su incursión en América (Alonso, 2009, p. 18). Luego se pensó que la función más idónea de Filipinas, además de ocasionarles gastos a los enemigos de la monarquía, sería la de ser el punto de intermediación comercial entre el sudeste asiático y América.

El trasiego de personas y mercadería por el Pacífico hispánico adquirió un ritmo regular cuando se estableció el comercio entre México y Filipinas luego del viaje que hiciera Andrés de Urdaneta en 1565, quien encontró una ruta viable y segura para la navegación entre Asia y América. Se creó, entonces, una miniflota similar a la atlántica -el llamado Galeón de Manila- que debía servir de apoyo a la colonización española de las islas Filipinas y hacer posible el nuevo intercambio comercial de América con Asia. Los géneros asiáticos (textiles, especias, porcelanas, perfumes, joyas) encontraron una salida inmediata en los mercados americanos, de manera que el comercio indiano con Oriente fue una actividad que floreció desde 
la década de 1580, al punto que preocupó seriamente a las autoridades de gobierno y al gremio de comercio sevillano (Suárez, 1995, p. 34).

La Casa de la Contratación -está casi de más decirlo- no lo aproba$\mathrm{ba}$, pues consideraba que este tráfico significaba una fuga de metales que mermaba el comercio con España. Luego de que en 1581 el gobernador de Manila, don Gonzalo Ronquillo de Peñalosa, enviara a Lima un cargamento de "cañones", porcelanas y sedas -inaugurando así el tráfico directo entre Manila y la ciudad de Los Reyes (Iwasaki, 2005, pp. 23 y ss.)-, Felipe II prohibió el comercio directo entre Filipinas y Perú en 1582 (prohibición que se reiteró en 1587), mientras que el producido entre México y Filipinas fue limitado a dos barcos y el envío de plata a 250000 ducados. Del mismo modo, las reexportaciones de bienes asiáticos de México a Perú fueron totalmente proscritas. Como es de suponer, estas medidas no hicieron más que propiciar un floreciente contrabando que involucró a las máximas autoridades virreinales. En 1587, por ejemplo, el virrey de México, marqués de Villamanrique, autorizó la salida de un navío perteneciente a Baltasar Rodríguez que transportaba productos chinos y filipinos, hecho que motivó la llegada de un recordatorio al virrey de que este comercio estaba censurado (Valle, 2005, p. 220). La desobediencia a las disposiciones que limitaban este tráfico llevó a las autoridades peninsulares a restringir aún más el comercio entre Perú y México, y entre el virreinato novohispano y las Filipinas. En 1604 se dispuso que sólo podrían salir de Nueva España hacia Filipinas dos naves de 200 toneladas cada una, mientras que el comercio entre los virreinatos debía limitarse a tres navíos que debían transportar exclusivamente productos de la tierra, aunque en 1609 se permitió exportar plata peruana hasta en 200000 ducados y en 1620 se prohibió la exportación de los vinos peruanos a Nueva España. Ya que el tráfico y, sobre todo, el contrabando no disminuyeron, las presiones siguieron y, en 1634, finalmente, llegó la real cédula del 23 de noviembre que prohibía todo comercio y navegación entre México y Perú por cinco años, la cual fue renovada hasta que se incorporó en la Recopilación de Leyes de Indias en 1680 (Escalona, 1775, lib. II, part. II, cap. XI, pp. 179 y ss.; Latasa, 1997, pp. 516 y ss.; Rodríguez 1960, p. 246).

Entre los diferentes actores involucrados en este tráfico, Lima y sus "peruleros" tuvieron una participación ambigua, pues a la vez que los mercaderes limeños invirtieron en este tráfico, aceptaron su cierre en 1634. No es fácil entender esta contradicción. Una fracción importante de las importaciones peruanas de México eran géneros asiáticos que encontraban una salida inmediata en el mercado peruano y compensaban los tiempos muertos de los galeones procedentes de Sevilla. Además -y probablemente antecediendo a las prácticas que aparecerían con más claridad en el siglo XVIII-, también se adquirían productos castellanos y europeos que 
importaban en demasía los mercaderes mexicanos (Bonialian, 2012, pp. 264 y ss.). No obstante, los comerciantes de Lima no se opusieron al cierre de tráfico formal entre los dos virreinatos.

Las explicaciones que se han dado sobre este hecho son diversas. Rodríguez Vicente (1960) planteó que la permisión de los 200000 ducados para el comercio con México no pudo ser monopolizada por los grandes comerciantes de Lima -cuyos intereses estaban vinculados al tráfico con España- y, en consecuencia, el comercio con México dañaba sus negocios atlánticos, por lo que consintieron su supresión (p. 249). Otros, como Latasa y Fariñas (1991), han planteado que los principales enemigos de esta ruta eran los comerciantes sevillanos y la propia corona, de suerte que poco pudieron hacer los comerciantes peruanos para mantener el tráfico legal, aunque optaron por el comercio interdicto hasta el siglo XVIII (p. 13; véase también Latasa, pp. 1997, pp. 513 y ss.). Flores (2005) propuso una explicación diferente. Para este historiador, el periodo de auge del comercio asiático peruano fue de 1590 a 1610, lapso en que algunos cargadores se enriquecieron tanto que luego pudieron competir exitosamente en el Atlántico. De esta manera, escalaron en el comercio europeo gracias al tráfico transPacífico y luego cerraron "la puerta tras de sî" para eliminar la competencia de nuevos personajes. Como no necesitaban más del comercio con México, exigieron su supresión (pp. 408-409). Finalmente, en un trabajo anterior planteé que, al restringirse el desembarco de productos asiáticos exclusivamente al territorio novohispano, se colocó a los comerciantes mexicanos en una posición privilegiada. Cuando este se prohibió, los comerciantes peruanos pudieron "imponer sus reglas de juego" a los mercaderes de México y, de esta manera, lograron medir mejor el flujo oriental y encubrirlo con el tráfico de azogue y el traslado de funcionarios, y bajo el disfraz del comercio con Guatemala y Panamá (Suárez, 2001, pp. 240-241). Siguiendo esta línea, el objetivo de este artículo es analizar cómo factores de índole comercial (la ofensiva perulera en el Atlántico y las saturaciones del mercado peruano) y los roces derivados de la intervención de funcionarios y la intermediación mexicana, llevaron a los comerciantes de Lima a apoyar el cese del tráfico legal con el fin de monopolizar el comercio ilícito entre ambas regiones.

\section{Entre el Atlántico y el Pacífico}

La Ciudad de Los Reyes constituía, sin duda, el nudo natural de los intercambios comerciales del virreinato peruano. Favorecida por ser la sede del gobierno y estar muy cerca del puerto del Callao, Lima no sólo fue el mayor centro meridional de la economía atlántica, sino también un eje 
sustancial del mercado interno colonial e intercolonial. La capital del virreinato gozaba de ventajas y privilegios, pero las condiciones de los comerciantes y del mercado peruano en las primeras décadas del siglo XVII eran inestables. Varios factores confluían en este desequilibrio. En primer lugar, al haberse negado los comerciantes a fundar un consulado a fines del XVI para evitar ser blanco de obligaciones impositivas, era difícil controlar a aventureros que confiaban sus capitales a advenedizos o a peninsulares recién llegados que recurrentemente distorsionaban el mercado peruano. La fundación del Tribunal del Consulado, en 1613, fue un paso importante para corregir este problema, pero resultó claro que no era el único, y que tampoco fue suficiente (Suárez, 1995, pp. 28-29). En segundo lugar, las condiciones en el istmo de Panamá eran complicadas, puesto que los arrieros extorsionaban a los comerciantes con fletes altísimos, los gobernadores de Tierra Firme cobraban sustanciosos cohechos y los mercaderes sevillanos continuaban con la pretensión de controlar el flujo de mercaderías en las ferias con el fin de vender a los peruanos artículos a precios elevados. Cuando los mercaderes peninsulares no lograban colocar sus productos en las ferias, viajaban a Lima para venderlas o rematarlas, lo cual causaba desajustes en el stock de géneros y, en consecuencia, la saturación del mercado peruano. En estas condiciones, el comercio asiático no siempre fue bienvenido por los grandes cargadores debido a que, de igual manera, distorsionaba los ritmos del comercio atlántico. Para empeorar el escenario, el monarca había adquirido la costumbre de confiscar la plata procedente de América para abonar sus deudas, lo que, unido al aumento de tasas fiscales sobre el comercio, había obligado a los comerciantes a eludir los pagos en la medida de lo posible, y de manera desvergonzada en no pocas ocasiones. Por último, la producción de plata potosina ya sufría las consecuencias del agotamiento de las vetas superficiales y estaba siendo afectada por las consecuencias políticas de las medidas correctivas adoptadas para subsanar el déficit de la caja por las deudas de azogue de los mineros. Estos hechos no derrumbaron la producción -pues se invirtió en nuevas minas-, pero no cabe duda de que la suma de todos estos factores alteraron el panorama económico en el que se manejaban los negocios comerciales (Suárez, 2001, cap. 3).

Los grandes comerciantes de Lima respondieron creativamente a este conjunto de condiciones y, como es natural, su objetivo estaba encaminado a desarrollar mecanismos para controlar de manera eficaz los distintos frentes que se habían abierto. El crédito fue la clave de su éxito. Desde fines del siglo XVI, algunos mercaderes de Lima comenzaron a realizar operaciones bancarias en sus casas mercantiles. Esto obligó al Cabildo a legislar y ordenar el funcionamiento de estas entidades, que adquirieron el título de "bancos públicos". Es así que, desde 1608 hasta 1640, existieron 
en Lima siete bancos: los de Baltazar de Lorca, Juan Vidal, Juan López de Altopica, Diego de Morales, Juan de la Plaza, Bernardo de Villegas y Juan de la Cueva. La ciudad de Lima, de esta manera, fue la única plaza de toda la América hispana que contó con este tipo de entidades financieras durante todo el periodo virreinal. El crédito -y, específicamente, el brindado por los bancos de Lima- desempeñó un papel fundamental en la conformación de grandes consorcios mercantiles, ya que colocaba a sus miembros en una mejor posición respecto a aquellos que no tenían el financiamiento de los bancos. Estos conglomerados -compuestos por un banco, mercaderes regionales, propietarios de medios de transporte terrestre y marítimo, y productores agrícolas y manufactureros- operaban conjuntamente por varios años, con la ventaja de tener una red de confianza establecida y acceso al crédito inmediato. Del mismo modo, los consorcios desplegaban sus negocios en un espacio muy amplio, lo que implicaba que no se dedicaban exclusivamente a ningún rubro en particular ni operaban en un sola ruta y, claro está, tampoco lo hacían fuera del grupo (Suárez, 2001, pp. 95 y ss.).

La formación de estos consorcios colocó a los grandes mercaderes de Lima en un lugar privilegiado en el comercio a larga distancia. Los "peruleros", es decir, los factores de las casas limeñas, no sólo compraban en Sevilla, sino también circulaban por "el señorío de Vizcaya y otras partes de España, Portugal, Génova y Milán", por las rutas de comercio portugués y, finalmente, por el Pacífico. En Europa obtenían crédito de comerciantes extranjeros y se comprometían a pagar en Lima o Portobelo, de manera que las ferias perdieron paulatinamente su función de punto de intercambio y se convirtieron en espacios de papel, con el agravante adicional de que eludían masivamente las imposiciones fiscales, como se pudo apreciar con claridad tras la denuncia, en 1624, del tesorero Cristóbal de Balbas -"cismático de la conservación del mundo"2 (véase también Vila, 1984). La denuncia del fraude iba de la mano con la acusación de que eran los peruleros, en alianza con los extranjeros, los que estaban distorsionando el sistema comercial. Sólo para mencionar algunos ejemplos, puesto que las imputaciones abundan desde el siglo XVI, en 1617 el secretario de la Casa de la Contratación pidió que se prohibiese terminantemente el arribo de peruleros a España (Bernal, 1992; Chaunu, 1955-1959; García, 1997; Lynch, 1993; sobre la ofensiva "perulera" y el sabotaje de los comerciantes en Lima al régimen de los galeones véase Suárez, 1993, 1995, 2001; Veitia y Linaje, 1945; Vila, 1984). En 1622, Francisco de Mandojana, en su infor-

\footnotetext{
${ }^{1}$ Archivo General de la Nación del Perú (en adelante AGNP), sección Notarial, Diego Nieto Maldonado, año 1629a, leg. 1224, fols. 2362r-2370v.

${ }^{2}$ Archivo General de Indias, Sevilla, España (en adelante AGI), Consulados 50. Carta del Consulado de Sevilla a Gonzalo Romero. Sevilla, 10 de abril de 1626, fols. 1r-2r.
} 
me para mejorar el comercio con las Indias, decía que "muchas personas y espeçialmente los encomenderos que bienen [sic] de las Yndias a emplear con caudales ajenos, acostumbran comprar sin los tener propios 100 000, 200 000, 300000 ducados cada uno fiados a pagar en las Yndias y entre todos mas de dos millones" y con esta práctica se estaba distorsionando la fluidez del tráfico con Perú y se beneficiaban los extranjeros. ${ }^{3} \mathrm{Y}$ el Consulado de Sevilla, en 1626, también intervino con una larga carta a su similar en Lima, en la cual imploraba -"por amor a Dios"- evitar que sus factores viajaran a Sevilla. El gremio sevillano explicaba que eran tan desmesurados los créditos que obtenían los factores peruanos en Sevilla que "la tierra [estaba] perdida y agotada [... y por ello] hemos querido proponer a VM el [asunto] de los Peruleros por uno de los más dañosos y perjudiciales a ambos comercios". ${ }^{4}$ El Consulado de Sevilla pedía, pues, que retomaran su correspondencia mercantil con los mercaderes de Sevilla, lo que no acarreaba peligros y, sobre todo, los eximía del odio de los ministros. ${ }^{5}$

En esta guerra de agentes comerciales, que había comenzado en el siglo XVI y se prolongaría hasta el siglo XVIII, los peruleros tenían ciertas ventajas: el acceso directo a la plata producida en el reino (gracias a la formación de los consorcios mencionados) y la avidez de los comerciantes extranjeros por buscar interlocutores comerciales en América. Pero, además, gozaban de cierta inmunidad frente a los intentos del Consulado de Sevilla de manejar el mercado peruano debido a que también se hallaba abierta la puerta al Asia. En las primeras décadas del XVII aparecieron múltiples informes de la Casa de la Contratación y del Consulado de Sevilla que calificaban al tráfico con las Filipinas como una de las principales causas del deterioro del comercio atlántico, junto con la presencia de los peruleros. El arbitrio de Pedro de Avendaño Villela al rey, fechado en 1608, es elocuente. Sostenía que el comercio con España había disminuido en tanto el tráfico con las Filipinas había aumentado, y que si se llevaran a España los 2000000 de pesos que se remitían al Asia en cada galeón, valdrían seis una vez invertidos en la península; el rey cobraría derechos y aumentaría su patrimonio; también se beneficiarían los vasallos de España y, por último, “estarán las Indias necesitadas a la dependencia della, que no es lo menos importante para su seguridad". La solución que ofrecía Avendaño para este problema era radical: "ha de ser servido (VM) de

${ }^{3}$ AGI, Consulados 93. Informe. Razones que expuso Francisco de Mandojana, a quien cometió el Comercio el informe de los medios que le ocurriesen para mejorar el estado del Comercio. Sevilla, 5 de marzo de 1622, fol. 9r.

${ }^{4}$ AGI, Consulados 50. Carta del Consulado de Sevilla al Consulado de Lima, Sevilla, 18 de abril de 1626 , fols. $8 \mathrm{r}-9 \mathrm{v}$.

${ }^{5}$ AGI, Consulados 50. Carta del Consulado de Sevilla al Consulado de Lima, Sevilla, 18 de abril de 1626 , fols. $8 \mathrm{r}-9 \mathrm{v}$. 
mandar que la Corona de Castilla trueque con la de Portugal las Islas Filipinas, por el Brasil, y que aquellas [las Filipinas] se goviernen por el Consejo de Portugal, y se naveguen por la India Oriental, quitando de todo punto qualquiera embarcacion, trato, y passage a ellas por la Nueva España, y el Piru". ${ }^{6}$

Si bien esta "solución final" de Avendaño no se llevó a la práctica, lo cierto es que el comercio de Perú con México se fue cerrando paulatinamente, aunque la presencia de mercaderías chinas se mantuvo, como lo demuestran los navíos de permiso que fueron a México y Centroamérica, las mercaderías que enviaron los mexicanos a Perú, la presencia de "indios" asiáticos en Lima y la de numerosos objetos orientales que aparecen en los inventarios de los testamentos de vecinos de Perú. ${ }^{7}$ Sin embargo, este tráfico afectó de muchas maneras a los peruleros, quienes verían con alivio su prohibición a partir de 1634 .

El COMERCIO Y SUS LABERINTOS: LOS NAVÍOS A MÉXICO DE 1612 Y 1629

En 1633, el notario limeño Bartolomé de Cívico asentaba en sus registros el testamento de Francisco Moreno Donoso, muerto en Manila en 1630. El documento había sido mandado a abrir en Lima por su esposa, doña Francisca de Mendoza, residente también en la capital del archipiélago. La historia que se puede reconstruir a partir del testamento es un vívido ejemplo de los avatares de los hispanos que recorrían un mundo recientemente "conectado". Moreno confesaba ser oriundo del condado de Medellín, en Extremadura, y que había pasado a Perú en compañía de su hermano, Pedro Martín Moreno, en 1594. En Lima desposó a doña Nicolasa de Bernuy, quien le había entregado como dote la suma de 22000 pesos. La compañía comercial con su hermano había ido cuesta abajo. Tras regresar a España y volver nuevamente a Perú, el hermano lo había endeudado en gran suma "de ducados sin quenta y razón": perdió 50000 pesos ensayados y debía una cantidad grande a diferentes personas en el país. Con permiso de su mujer, viajó a las islas Filipinas en 1601 y recibió encomien-

${ }^{6}$ AGI, Consulados 93. Expuesto de don Pedro de Avendaño Villela al rey sobre la decadencia del comercio de Buenos Aires y el Perú por la comunicación clandestina que [roto] el Brasil y propone su remedio. Madrid, 14 de abril de 1608, s. f. Un estudio sobre este arbitrio elaborado por García de los Arcos sobre la base de una copia encontrada en la Biblioteca Británica se puede encontrar en "Una propuesta".

${ }^{7} \mathrm{El}$ censo de indios de Lima que ordenó hacer el virrey Montesclaros arrojó que había 114 personas de "la China, Xapon e yndias de Portugal”. Biblioteca Nacional de España, MSS3032, "Padron de los indios", año 1613, fols. 246r-v. Sobre la presencia de objetos orientales en las casas limeñas, véase, por ejemplo, la descripción de la casa del banquero Juan de la Cueva en Suárez, 2001, pp. 82 y ss. 
das en la provincia de Otón. Pero lamentablemente le habían salido mal todos sus negocios comerciales, de manera que debía más de lo que tenía, aunque en Lima se dijese que en las islas se había vuelto rico. Así, el moribundo daba directrices para cumplir, en la medida de lo posible, con sus obligaciones con el fin de poder morir en paz. ${ }^{8}$

El caso de Moreno muestra el incansable movimiento de los españoles de la época, provistos de espíritu aventurero, ansiosos de obtener fortuna y capaces de atravesar dos océanos para hacer realidad sus sueños. Algunos españoles llegaban a las islas ávidos de obtener encomiendas y tierras, pero la experiencia muestra que los oficiales debían reclutar por la fuerza a jóvenes que no tenían nada que perder, excepto la vida, en el conflictivo territorio insular (García, 1996, pp. 72 y ss.). Los comerciantes, por su parte, estaban dispuestos a emprender este largo viaje e invertir en el comercio asiático por los altos márgenes de utilidad que, a su vez, eran la contraparte de los bajos precios de los géneros chinos y de los cortos plazos de retorno de las ganancias. Además, esta ruta era el complemento perfecto del tráfico de cabotaje que partía de Lima. El comercio con México era una prolongación del comercio peruano con Panamá y Guatemala; los navíos viajaban al norte con pasas, conservas, aceitunas, mercurio y, sobre todo, cacao, vino, vinagre y plata, y regresaban con mercaderías asiáticas y europeas obtenidas en la ciudad de México, y con productos de la tierra (brea, madera, añil, bálsamo y palo de Campeche).

A pesar de los reiterados reclamos de los comerciantes y las autoridades peninsulares, la ruta asiática nunca fue para Lima una alternativa excluyente a la atlántica, sino más bien un complemento, sobre todo cuando la ofensiva perulera puso a la ciudad en una posición ventajosa en el tráfico con Europa. El comercio con México, así como el atlántico, estaba en manos de los grandes cargadores limeños, aunque también es cierto que intervinieron regidores del Cabildo, algunos clérigos y funcionarios públicos. El análisis realizado por Flores (2005) de los actores involucrados en el comercio con México entre 1601 y 1608 muestra que los propietarios de navíos eran los factores más importantes en este tráfico, como Diego de Simancas, Juan González de la Parra, Alonso González de la Canal o Jacome de Quesada. Asimismo, figuran como inversionistas otros destacados comerciantes del tráfico atlántico: Jerónimo Justo de Porras, Gabriel Recio de Castilla, Juan Bautista Crespo, Juan de Urrutia, Diego de Otazu, Tomás de Mañara o los banqueros Juan López de Altopica y Baltasar de Lorca (pp. 398 y ss.). Todos ellos participaron en la fundación del Tribunal del Consulado de Lima en 1613, y eran grandes cargadores y financistas del comercio limeño. Que el comercio en el Pacífico los haya enriqueci-

${ }^{8}$ AGNP, sección Notarial, Bartolomé de Cívico, año 1633, leg. 336, fols. 2763r-2800v. 
do para después sacar ventajas en el Atlántico, como plantea Flores, es relativo, puesto que la mayoría de estos comerciantes eran miembros de los grandes consorcios transatlánticos que habían decidido operar desde Lima. Tomás de Mañara, por ejemplo, era natural de Calvi, en la isla de Córcega, fue administrador de la avería en Sevilla, y él y sus hermanos eran parte de una red en la que participaron Antonio de la Cueva y su hermano, el futuro banquero Juan de la Cueva, así como el banquero Baltasar de Lorca, Diego Correa y Miguel Ochoa (Suárez, 2001, pp. 60 y ss.). ${ }^{9}$ Casi todos los mercaderes que figuran en el comercio asiático en la primera década del XVII eran peruleros, de origen sevillano, que se iniciaron en la carrera de Indias como factores de casas sevillanas y luego se afincaron en Lima; seguidamente organizarían empresas de envergadura vinculadas al mercado interno y, así, invertían en el comercio asiático como parte de una estrategia más amplia de diversificación de sus negocios.

La revisión de las escrituras notariales de 1612 y 1629, en cuyas fechas se embarcaron navíos a Acapulco, confirma esta tendencia, aunque ciertamente aparecen algunas particularidades..$^{10} \mathrm{El}$ año de 1612 fue un punto de quiebre de la posición de Lima frente a esta ruta, puesto que se desencadenaría una ola de quiebras que, en parte, fue atribuida al impacto del comercio con México sobre el mercado peruano. En el cuadro 1 se observa que en 1612 el monto total del dinero enviado a México fue modesto, inferior al medio millón de pesos; si se le agregan los poderes para contraer obligaciones, se estaría hablando de poco más de 600000 pesos de ocho reales envueltos en este tráfico según fuentes notariales. Si se examina esta remisión por rubros, se puede apreciar que tan sólo 274858 pesos $(46 \%)$ estaban destinados a la compra de mercaderías, 121891 pesos (20\%) se enviaban para pagar obligaciones contraídas previamente por comerciantes peruanos en México, 41531 pesos (7\%) eran remisiones de plata por venta de mercaderías pertenecientes a comerciantes mexicanos, 48584 pesos $(8 \%)$ debían entregarse a diferentes personas por conceptos no especificados y, finalmente, 114726 pesos (19\%) eran cartas firmadas por comerciantes peruanos con poderes para endeudarse en México. La mayor parte de este dinero era para entregar en la ciudad de México, no en Acapulco. Fue una constante el envío de dinero directamente a la ciudad de México -o, en su defecto, a la de Manila-, y desde 1612 hasta 1629 las escrituras peruanas no hacen ninguna mención a las "ferias de Acapulco". ${ }^{11}$ Así, todo

\footnotetext{
${ }^{9}$ AGI, Contratación 5172.

${ }^{10}$ Se han revisado los 50 legajos notariales de 1612 y 1629 del AGNP para extraer las cifras y la información de los comerciantes involucrados en este tráfico. Se hallaron 316 escrituras referidas al comercio con México.

${ }^{11}$ Sobre la función de Acapulco en este periodo, véase Yuste (2013, pp. 88 y ss.).
} 


\section{CUADRO 1. RUBROS EN EL COMERCIO CON MÉXICO, AÑO 1612}

Rubros

Comprar mercaderías

Pagar obligaciones en México

Cartas-poderes para obligarse

Entregar a diferentes personas

Por venta de mercaderías de comerciantes mexicanos en Lima

Total
Pesos de a ocho reales

274858.4

121891.4

114726

48584

41531.2

601591.2

Fuente: elaboración propia con base en AGNP, sección Notarial. Año 1612.

parece indicar que, durante el periodo de tráfico permitido del comercio triangular, Acapulco no cumplió la función de feria comercial.

La composición de los factores varía un poco respecto a los que recibían dinero en la década precedente trabajada por Flores (2005), y también aumenta la cantidad de plata consignada individualmente. Como se aprecia en el cuadro 2, Pedro Pardo de Aguiar, quien sería acusado de contrabandista por este circuito en 1615 (Rodríguez, 1960, p. 390), recibió más de 90000 pesos de ocho reales. Juan Alarcón de Herrera, Juan de Munive, Martín Recio de Castilla, Martín López Caballón y Nicolás de Guadalupe, los cuales figuran aquí recibiendo importantes sumas, eran vecinos de Lima que aparecían indistintamente en la ruta de Portobelo, en el comercio de cabotaje y en el tráfico de mercaderías que se enviaban como parte del situado de Chile (Suárez, 2001, pp. 284, 219 y 331). Tanto Diego del Peso como Francisco de Palencia preferirán esta ruta para sus operaciones comerciales, al punto que este último fue acusado de contrabando en 1613, 1615 y 1620 (Rodríguez, 1960, p. 390; Suárez, 2001, p. 244). ${ }^{12}$ El maestre del navío San Francisco, Ruy Diez de Medina, no sólo recibió más de 36000 pesos, sino que también obtuvo poder de los dueños del navío, Juan de la Fuente Almonte, vecino de Lima, y su célebre tío homónimo, vecino de Panamá, para que conjuntamente con Pedro de la Barrera, vecino de la ciudad de México, pudiesen fletar el navío y comprar, con lo procedido del flete, mercaderías a su nombre. ${ }^{13}$ Esta práctica de fletar los navíos en México, e incluso venderlos, será frecuente. El 11 de diciembre de 1612, Jerónimo López de Saavedra, dueño de las dos terceras partes del navío San Diego, daba poder a Cristóbal de Bonilla Bastidas, vecino de la

12 AGI, Escribanía de Cámara 503 A.

${ }^{13}$ AGNP, sección Notarial, Cristóbal de Vargas, año 1612, leg. 1987, fols. 2916r-2917v. 
CUADRO 2. FACTORES DEL NAVÍO DE PERMISO A MÉXICO, ANO 1612

\section{Factores}

Pedro Pardo de Aguiar

Juan Alarcón de Herrera

Nicolás Guadalupe

Rodrigo de Robles

Ruy Diez de Medina

Juan de Munive

Martín Recio de Castilla

Francisco de Palencia Aponte

Bernardino Ramírez

Rodrigo de Ayan, de partida a Manila y China

Diego del Peso

Bernabé Bautista

Martín López Caballón

Otros

Total
Pesos de ocho reales

91886.1

68095

52641

44782

36730.6

33165

23405.5

21925

20428.4

17600

13993

11370

8560.6

42281.4

486864.2

Fuente: elaboración propia con base en AGNP, sección Notarial. Año 1612.

ciudad de México, y a Pedro Pardo de Aguiar para que pudiesen vender allí sus partes del navío con sus esclavos. ${ }^{14}$ Igualmente, el 7 de diciembre de 1612 Juan de Munive, residente en Lima, recibía un poder conjuntamente con el capitán Martín de Ormachea, residente en la ciudad de México, de su hermano, Lope de Munive, vecino de Lima, para que cobrasen de Martín de Zamudio, quien fuera maestre de su navío San Andrés, de lo procedido por el fletamento de su navío en el puerto de Acapulco y en el "reino de la China". ${ }^{15}$

Tres de los factores del año 1612 no residían en Lima. Rodrigo de Robles, por ejemplo, era vecino de Acapulco, y llegó como maestre del navío San Juan Bautista (otro de los que aparecen en la ruta asiática). Como tal, hubo de asumir las cuentas y cobrar las obligaciones a favor de Juan Bravo de Laguna, quien muriera en dicho navío cuando se hallaba en el puerto

\footnotetext{
${ }^{14}$ AGNP, sección Notarial, Cristóbal de Vargas, año 1612, leg. 1987, fols. 2928r-v. El dueño del otro tercio del navío era Martín López Caballón.

${ }^{15}$ AGNP, sección Notarial, Diego Sánchez Vadillo, año 1612, leg. 1727, fols. 1113r-1114v.
} 
de Manta; ${ }^{16}$ la mayor parte del dinero que recibió en Lima fue para pagar a acreedores residentes en Acapulco y México. ${ }^{17}$ Igualmente, Bernabé Bautista, vecino de México, llegó a Lima a cobrar dinero de sus corresponsales de la capital del virreinato novohispano: Pedro de Pedrosa, Bartolomé Fermín, Miguel de Neve, Melchor de los Reyes y Francisco de Rivera Prieto. ${ }^{18}$ Otro caso interesante es el de Rodrigo de Ayán, quien se encontraba en Lima "de partida a Manila y China", y recibió un total de 17600 pesos. $^{19}$ Los recibos de dinero muestran conexiones fluidas entre Lima, Acapulco y Manila. Por ejemplo, en la escritura que recibe 6000 pesos de Andrés López de Carcaya se le daban instrucciones para que empleara en Manila el dinero según una memoria que se le había entregado y luego embarcase los géneros a costa de López con destino al Callao; por su trabajo obtendría dos tercios de las ganancias del empleo de las mercaderías (a diferencia de las ganancias atlánticas del factoraje, que eran de 20\%). ${ }^{20}$ Varios de los personajes que confiaron su dinero en las manos de Ayán nombraron a las mismas personas como respaldo en caso de que este no cumpliera con sus compromisos. En Acapulco, figuran nombres como Manuel de Castillo -escribano de registros-, Rodrigo de Robles, Mateo de Landa y Feliciano de Lear. En Manila, los encargados de llevar los negocios en caso de incumplimiento de Ayán serían Marcos de la Cueva, Bartolomé Tenorio, Pedro de Anciondo y don Juan de Alvarado Bracamonte, fiscal de la Audiencia de Filipinas.

En cuanto a los sujetos que envían dinero en este navío de permiso de 1612, la mayoría eran comerciantes de reconocida trayectoria en Lima, como Juan Marmolejo, Jerónimo López de Saavedra, Bartolomé González, Lope de Munive, Bartolomé Lorenzo, Diego de Otazu o Antonio de Ureña (véase gráfica 1). Que Nicolás de Mendoza y Carbajal encabece la lista con 37000 pesos sí es singular, aunque se sabe que los negocios del corregidor del Cusco estaban bien diversificados. Mendoza y Carbajal fue el mayor deudor del banco de Juan de la Cueva, y sus malos manejos lo llevaron a la quiebra, cuando hubo de vender tierras y obrajes al banquero (Suárez, 2001, pp. 86, 149, 157-159, 161, 182, 433). Otro personaje que podría parecer fuera de lugar es el del clérigo Juan de Robles, receptor del Santo Oficio y mayordomo de la catedral de Lima, pero bien se sabe que este era un importante hombre de negocios, cuyas operaciones estuvieron

\footnotetext{
${ }^{16}$ AGNP, sección Notarial, Cristóbal de Vargas, año 1612, leg. 1987, fols. 2189 r. y ss.

${ }^{17}$ AGNP, sección Notarial, Pedro Juan de Rivera, año 1612, leg. 1611, fols. 600r-v.

${ }^{18}$ AGNP, sección Notarial, Cristóbal de Vargas, año 1612, leg. 1987, fols. 3061r-3062r.

${ }^{19}$ Aparentemente Ayán había vivido y casado en Lima con doña Francisca Bravo de Laguna, a quien le da un poder general para cobrar y vender en 1612. AGNP, sección Notarial, Diego Nieto Maldonado, año 1612, leg. 1200, fols. 1230r-1231v.

${ }^{20}$ AGNP, sección Notarial, Diego Nieto Maldonado, año 1612, leg. 1200, fols. 1017v-1020v.
} 


\section{GRÁFICA 1. COMERCIANTES QUE ENVIARON DINERO EN EL NAVÍO DE PERMISO, AÑO 1612}

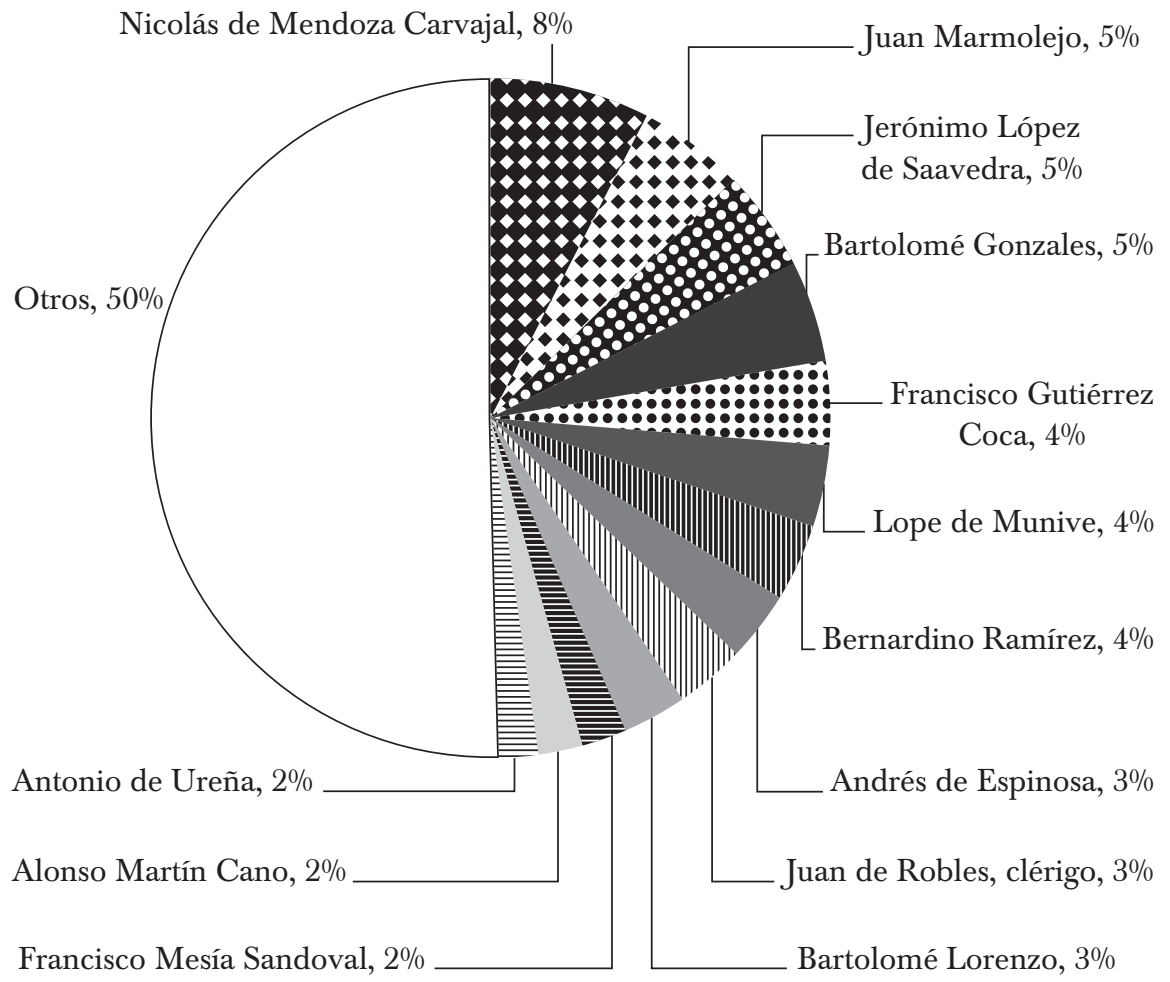

Fuente: elaboración propia con base en AGNP, sección Notarial. Año 1612.

vinculadas a la comercialización de diezmos, la fundación de conventos y a préstamos a la Caja Real de Lima (Suárez, 2001, pp. 27-28). Fruto de sus negocios en la ruta del Pacífico, en 1613 Robles aparece como acreedor de una obligación contraída por Manuel Juárez, vecino de Ica, por un monto de 29046 pesos de ocho reales por la venta de mercaderías de México; en la escritura se declara que el costo de las mercaderías en México ascendía a 18154 pesos, pero que el precio en Perú era 60\% superior por el "interés [...] sobre el dicho costo que como dicho es tuvieron en la dicha ciudad de México". ${ }^{21}$ Por último, otro personaje aparentemente inusual fue Francisco Mesías Sandoval, capitán de la guardia del virrey marqués de Montescla-

${ }^{21}$ AGNP, sección, Notarial, Diego Sánchez Vadillo, año 1612b, leg. 1727, fol. 1090v. 
ros, quien enviara casi 10500 pesos. Según sus instrucciones, el dinero debía entregarse a Jorge de Andrada, vecino de México, por mercaderías que envió a Manuel Correa, presbítero, y al propio Mesías, que finalmente fueron vendidas al maestre de navío Juan de Arresti. ${ }^{22}$ Esta práctica, la de que criados de los virreyes estuviesen involucrados en el tráfico, era bastante frecuente, e incluso que estos actuaran como testaferros de los negocios del virrey, aunque aquí no se hace ninguna mención al vicesoberano.

Finalmente, las cartas de pago canceladas en Lima antes de la salida del navío a México en 1612 (véase diagrama 1) revelan que existía una red constituida de agentes limeños de mercaderes mexicanos en Lima, quienes se encargaban de recabar las deudas pendientes en territorio peruano. Tres son los comerciantes más importantes: Juan de Urrutia -quien encabeza incuestionablemente la lista-, Jerónimo López de Saavedra y Francisco Ramírez de los Olivos. Urrutia era vizcaíno; sería cónsul del Tribunal en 1623-1624, prior en 1631, 1634 y 1638, y uno de los más cerrados defensores del comercio con México, como se verá más adelante. Fue uno de los financistas del altar de Nuestra Señora de Aránzazu, en la iglesia de San Francisco, e hizo traer de España una copia de la Virgen para la cofradía de los vascongados. En la época, esta congregó a los vascos más importantes de Lima, muchos de ellos comerciantes, y el traslado de la imagen de la Virgen desde la catedral hasta San Francisco se hizo en una célebre procesión encabezada por el virrey Mancera, en 1646 (Rodríguez, 1960, p. 392). López de Saavedra también sería una figura notable del comercio peruano, se desempeñó como fiador de bancos, fue miembro del Cabildo y, sobre todo, ocupó el cargo de depositario general de Perú (Suárez, 2001, pp. 73, 100 y 123). Por último, Ramírez de los Olivos sería fundador del Consulado, prior en 1620 y 1627, y prestamista para la Armada (Rodríguez, 1960, p. 390).

Estas conexiones entre comerciantes mexicanos y limeños fueron frecuentes e incluso trascendieron el circuito del Pacífico. En 1615, por ejemplo, Nicolás de Zavala, cónsul del Tribunal, entabló una causa contra Bernardino Ramírez, también vecino de Lima, por el empleo de mercaderías que pertenecían a Diego Ramírez Bohórquez, vecino de la ciudad de México. Allí se puede observar una instrucción que establece que en caso de que no pudiesen enviar el dinero procedente de la venta de mercaderías a Nueva España, lo consignasen a Sevilla, comprasen en esta plaza las mercaderías que les parecieren y, de allí, se las remitiesen a Ramírez Bohórquez a la ciudad de México. ${ }^{23}$

\footnotetext{
${ }^{22}$ AGNP, sección Notarial, Pedro Juan de Rivera, año 1612, leg. 1611, fols. 639r-640v. Sobre los deudos y criados del virrey Montesclaros en el Perú véase Latasa, 1997, pp. 155 y ss.

${ }^{23}$ AGNP, Tribunal del Consulado, año 1615, Judicial, caja 145-3.
} 


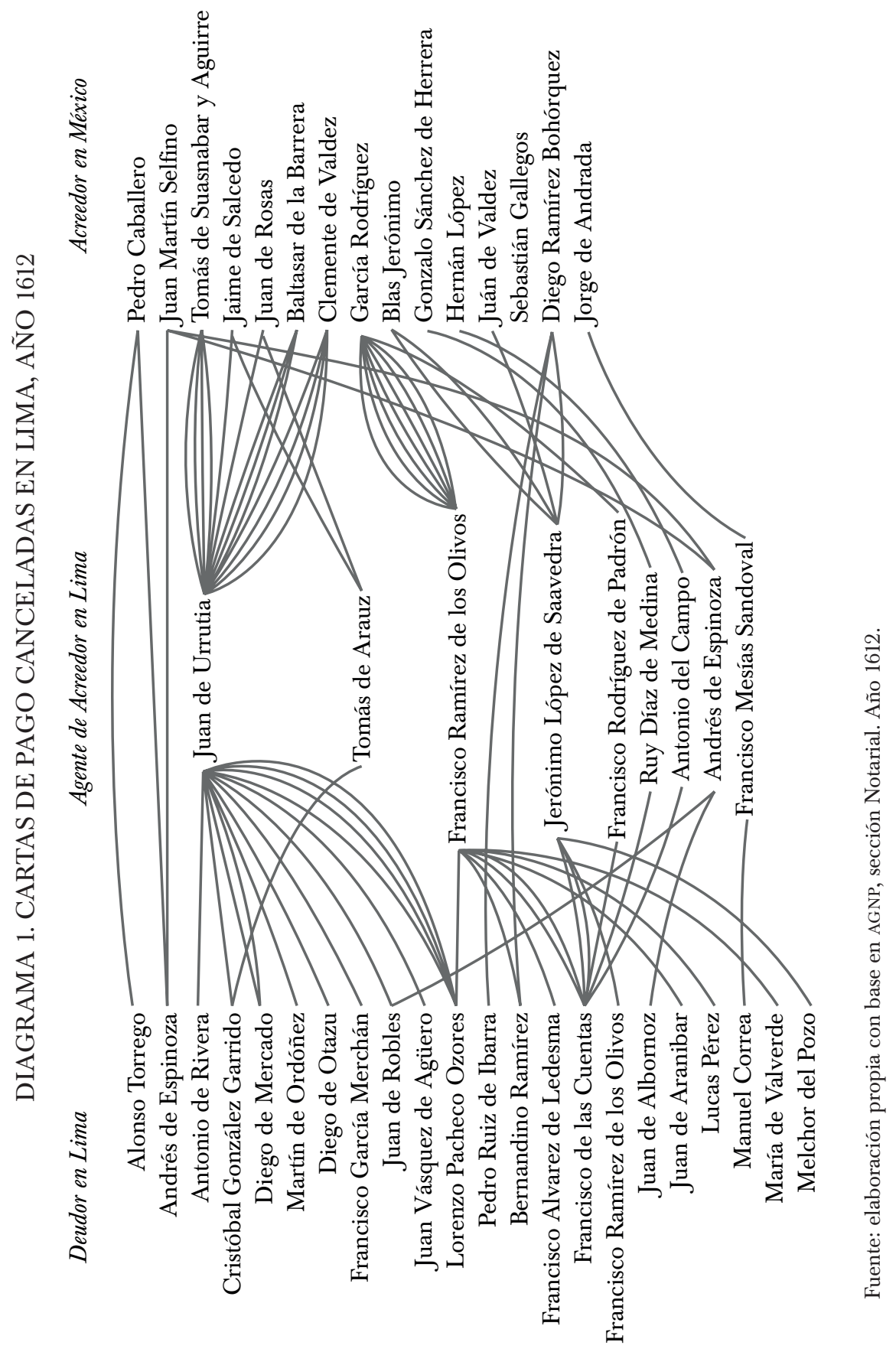


El navío de permiso de 1629 revela un patrón similar al de 1612, a pesar de que esta vez la influencia del banquero Juan de la Cueva fue sustancial. En el Diario de Lima se habla del envío de más de 2000000 de pesos en el navío San Francisco, de propiedad del banquero, a Nueva España (Suardo, 1936, vol I. p. 46). Los contratos notariales (véase cuadro 3) ofrecen cifras más modestas, con un total de 645526 pesos de los cuales $66 \%$ (428 833 pesos) tenía como finalidad la compra de mercaderías, lo cual quiere decir que en este navío de permiso fue más dinero "fresco" para la compra de mercaderías.

Del monto enviado $80 \%$ fue colocado en manos de cinco factores -Juan de Frías Ibarra, Esteban de la Cueva, Juan Osorio, Agustín de Uceda y Felipe de Espinosa y Mieses (véase cuadro 4). Se sabe que los factores Cueva, Espinosa y Mieses, Martínez de Soto y Ugarte eran parte del círculo del banquero Cueva o tuvieron negocios y/o cuenta en su banco. En cambio, la identidad del factor Frías Ibarra, el mayor receptor de dinero, es un enigma, puesto que no aparece con anterioridad en el círculo mercantil limeño. No obstante, realizará transacciones que muestran que tenía relaciones fluidas en la ciudad. Frías aparece como "residente en Lima", otorgando cartas de pago como, por ejemplo, aquella que firmó en nombre de Juan Lorenzo de Vera, vecino de la ciudad de México, gracias a un poder otorgado por el mexicano junto a Antonio de Urtarte, vecino de Lima. ${ }^{24}$ Del mismo modo, otorgó cartas de pago en nombre de Melchor de Cuéllar, ensayador mayor de la Casa de Moneda de México, quien tenía un rubro de negocios vinculados al virreinato peruano, aunque su agente habitual era Juan de Urrutia (Suárez, 2001, pp. 246-247). Incluso Felipe de Espinosa le entregó " 6 cortinas y cielo de cama con su sobrecama todo en terciopelo azul con flocaduras y alamares de oro" que pertenecían a Cuéllar y que Espinosa no pudo vender en Lima, ${ }^{25}$ y también vendió un esclavo chino "de casta bengala". ${ }^{26}$ Tenía, además, acceso al crédito en Nueva España, pues algunos comerciantes, como Cristóbal López de la Torre, le dieron poder a él y a Cristóbal de Bonilla Bastidas, vecino de la ciudad de México, para que lo obligasen hasta en 20000 pesos por compra de mercaderías. ${ }^{27}$

$\mathrm{Al}$ igual que en el navío de 1612, los factores tenían como encargo viajar a la ciudad de México para emplear mercaderías de acuerdo con la memoria entregada por el dueño del dinero. Los que invirtieron su dinero en el navío de permiso de 1629 fueron, como en 1612, grandes comerciantes

\footnotetext{
${ }^{24}$ AGNP, sección Notarial, Juan de Valenzuela, año 1629c, leg. 1954, fols. 732-736v.

${ }^{25}$ AGNP, sección Notarial, Diego Nieto Maldonado, año 1629b, fols. 3918-3920v.

${ }^{26}$ AGNP, sección Notarial, Jerónimo de Valencia, año 1629, leg. 1921, fols. 915v-916r.

${ }^{27}$ AGNP, sección Notarial, Diego Nieto Maldonado, año 1629b, leg. 1225, fols. 3666r-3667r.
} 
CUADRO 3. RUBROS EN EL NAVÍO A MÉXICO DE 1629

Rubros

Comprar mercaderías

Pagar obligaciones en México

Cartas-poderes para obligarse

Entregar a diferentes personas

Por venta de mercaderías de comerciantes mexicanos en Lima

Total
Pesos de ocho reales

428833.7

30664.7

94885

1003.4

90139.4

645526.2

Fuente: elaboración propia con base en AGNP, sección Notarial. Año 1629.

CUADRO 4. FACTORES EN EL NAVÍO DE 1629

\begin{tabular}{lc}
\hline Factores & Pesos de a ocho reales \\
& \\
Juan de Frías Ibarra & 188603.4 \\
Esteban de la Cueva & 116730 \\
Juan Osorio & 49601.5 \\
Agustín de Uceda & 45961.2 \\
Felipe de Espinosa y Mieses & 43926.1 \\
Pedro Martínez de Soto & 25185 \\
Juan de Ugarte & 24518.2 \\
Agustín de Ordóñez & 13346.7 \\
Esteban Castellanos & 9550 \\
Francisco de Bustamante & 7455.3 \\
Alonso Espinosa de los Monteros & 6610 \\
Francisco Cabello & 6400 \\
Francisco Rojo & 2464.6 \\
Otros & 10289 \\
Total & 550641.6 \\
\hline
\end{tabular}

Fuente: elaboración propia con base en AGNP, sección Notarial. Año 1629.

de Lima (véase gráfica 2). El banquero Juan de la Cueva encabeza la lista, con 65523 pesos y cartas-poderes por 17643 pesos; lo acompañan varios miembros de su consorcio, así como mercaderes vinculados a los negocios del Cabildo y la recolección de diezmos, como Melchor Malo de Molina, Pedro Sánchez Garcés y Juan Caballero de Tejada. Los únicos casos sin- 


\section{GRÁFICA 2. COMERCIANTES QUE ENVIARON DINERO EN EL NAVÍO DE 1629}

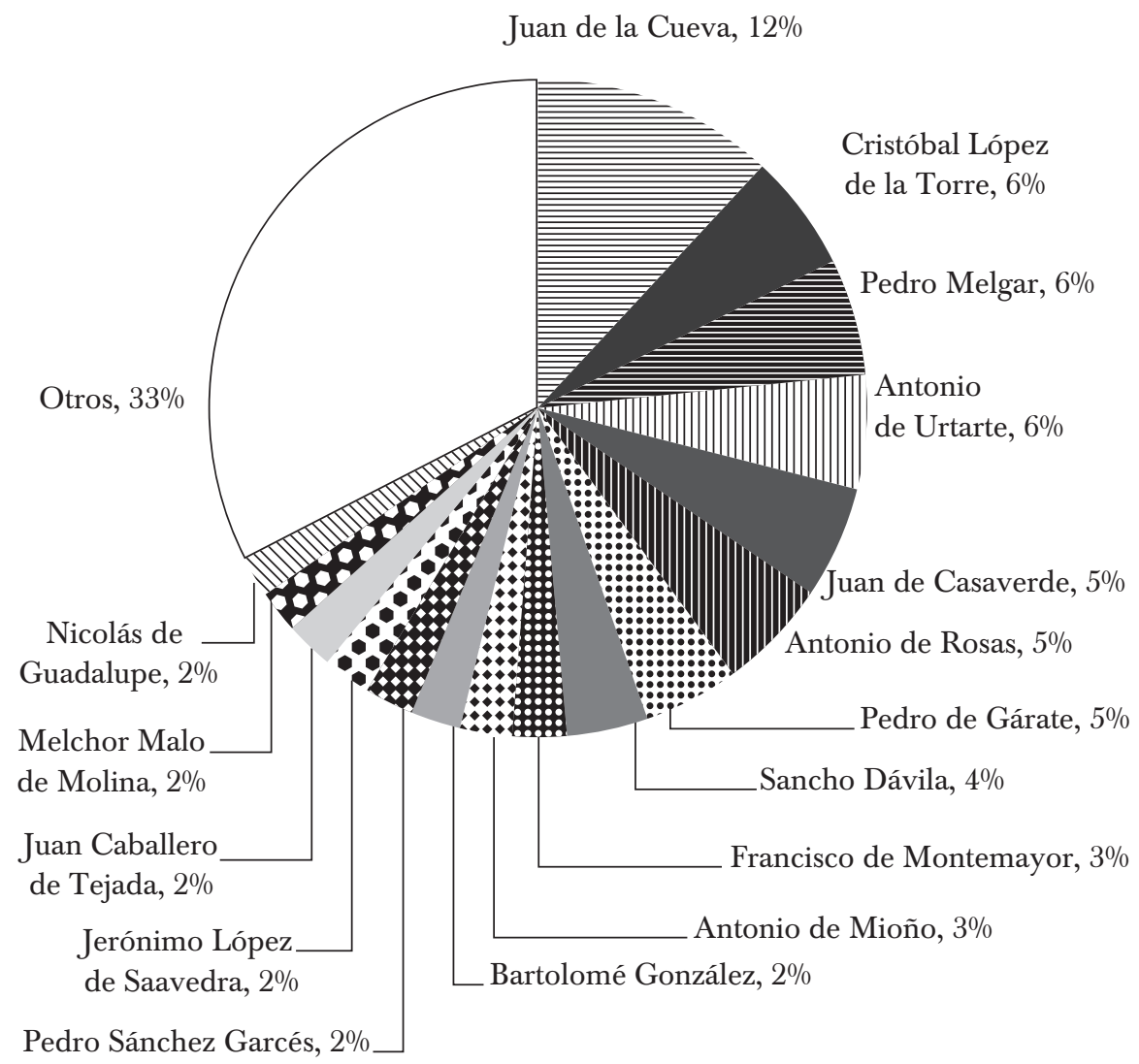

Fuente: elaboración propia con base en AGNP, sección Notarial. Año 1629.

gulares son la presencia del presbítero Alonso de Coca y del secretario Lucas Raimundo de Capdevilla, escribano del virrey conde de Chinchón, quien aparece enviando poco más de 8000 pesos a México a través de un testaferro, Diego Sáenz de la Cruz. ${ }^{28}$

Fuentes oficiosas revelan que este navío llevó mucha plata fuera de registro. Los oficiales reales de Lima le escribieron al rey que lo sospe-

${ }^{28}$ AGNP, sección Notarial, Diego Nieto Maldonado, año 1629b, leg. 1225, fols. 3769r-3771v, 3820r-3822r. 
chaban porque escucharon ciertos avisos de artillería. ${ }^{29} \mathrm{Y}$, como se verá más adelante, hasta el virrey estuvo envuelto en ello. Pero lo cierto es que esta aventura comercial terminó muy mal y tal vez el mayor afectado fue el banquero Juan de la Cueva. Él había enviado su navío San Juan Evangelista en años previos a Acapulco con el maestre Luis Simón de Lorca, y esperaba que los frutos de esta contratación de 1629, que se enviaba en otra embarcación, la San Francisco, volvieran en el San Juan Evangelista, pilotado por Juan de la Cueva Pacheco. ${ }^{30}$ Sin embargo, el rey tomó ambos navíos para la contratación de Manila, los cuales aparecen en 1631 como almiranta y capitana de la flota a Filipinas. ${ }^{31}$ Las consecuencias para el banquero y muchos de los que enviaron dinero a México fueron funestas: los empleos no se pudieron llevar de vuelta a Lima (y cuando, después de años, finalmente llegaron, acusaron a los comerciantes de contrabandistas), no se pagaron las obligaciones contraídas, Cueva se quedó sin navíos para llevar a cabo sus otros negocios y hasta el virrey de Perú montó en cólera con el banquero. De hecho, hay noticias de un vecino de Manila, en 1633, que declaraba que las islas estaban en "gran desorden" debido a la llegada de vecinos de Nueva España y Perú, los cuales habían llegado con tanta plata -calculaba entre 3000000 y 4000000 de pesos- que habían acaparado las mercaderías procedentes de China "y otras partes" para cumplir con las órdenes de los vecinos americanos, quienes les exigían la remisión de sus empleos prontamente, con un beneficio de tan sólo 10\% para los factores. De este modo, los americanos no guardaban ni hacían caso de la prohibición y, lo que es peor, estaban encareciendo todos los productos en Manila. El vecino en cuestión, el alférez Jerónimo de Fuentes Cortés, pedía al Consulado de Sevilla que los vecinos de Manila pudiesen enviar 500000 pesos en mercaderías a México para poder llevar de vuelta 1000000 en moneda, sin la intervención de los americanos. Por último, solicitaba que los gobernadores de Manila llegasen de Perú, y no de México, pues allí los mercaderes los sobornaban y hacían amistad con ellos. ${ }^{32}$

El desajuste provocado por el navío de 1629 llevó al cierre, en la práctica, del comercio con México, hasta la llegada de la real cédula en 1634 que anunciaba su clausura (Rodríguez, 1960, p. 246). Pero evidentemente la historia registrada en los contratos notariales no permite observar los manejos políticos que llevaron a tomar esta drástica medida. Las transac-

\footnotetext{
${ }^{29}$ AGI, Lima 114. Carta de los oficiales reales al rey. Lima, 8 de junio de 1630.

${ }^{30}$ AGNP, sección Notarial, Diego Nieto Maldonado, año 1629b, leg. 1225, fols. 3651r-3652v.

${ }^{31}$ Recuperado de http://home.windstream.net/cr33856 [Revisado: 15 de abril de 2014]; Suárez, 2001, pp. 89, 447 y ss. En los conciertos de pilotaje de los navíos que iban a México, siempre se colocaba una cláusula en caso de que el rey tomara el navío para ir a Manila.

${ }^{32}$ AGI, Consulados 313. Carta de Jerónimo de Fuentes Cortés al Consulado de Sevilla. Manila, 22 de octubre de 1633.
} 
ciones notariales sí muestran que los grandes cargadores de Lima estaban involucrados en este comercio, y que incluso algunos mantenían vínculos y contactos en Filipinas. También resulta claro que algunos mercaderes de Lima eran agentes de confianza de comerciantes de la ciudad de México, que la presencia de mercaderes novohispanos era activa, y que existía una red de confianza mercantil y financiera que entrelazaba Lima y la ciudad de México. Por último, resulta evidente que todavía no existían ferias comerciales en Acapulco y que muchos de los navíos peruanos fueron fletados a la fuerza por las autoridades para mantener el enlace con Filipinas. Para seguir los pasos de las maniobras políticas que terminaron en el cierre del comercio triangular, habrá que buscar las respuestas en fuentes distintas que ayuden a entender por qué aceptaron su clausura, si los mercaderes de Lima estaban tan involucrados en este tráfico.

\section{EL COMERCIO ASIÁTICO: GRANDES GANANCIAS, GRANDES PROBLEMAS}

La batalla por el cierre de la ruta que enlazaba Lima con México y Manila se libró en los pasillos cortesanos y judiciales de Madrid, Sevilla, México y Lima. Ya se mencionó que desde 1582 comenzaron a promulgarse reales cédulas destinadas a restringir el comercio de bienes asiáticos en América, y que en 1604 se volvió a limitar tanto el comercio de Perú con México como el tráfico entre el territorio novohispano y las islas Filipinas. Pero estas disposiciones no fueron acatadas. Cuando en 1607 el recién nombrado virrey de Perú, marqués de Montesclaros, recibió un recordatorio de que el ingreso de mercaderías chinas estaba prohibido, sólo pudo responder al monarca que había hecho "apretadas diligencias" para disminuir el tráfico, pero como ya se había despachado el dinero cuando llegaron las cédulas, no se pudo hacer mucho, a pesar de que el vicesoberano acababa de dejar el puesto de virrey de Nueva España y estaba al tanto de las restricciones. Incluso el mismo virrey había encargado ropa de China para enviar como situado a Chile, ya que parte de este se enviaba en dinero y la otra en mercaderías. ${ }^{33}$ No obstante, para mostrar signos de obediencia, la persecución a los comerciantes de productos chinos se inició casi de inmediato. En 1611 Alonso de San Juan denunció y el fiscal procesó a Francisco de Palencia y otros factores por las mercaderías prohibidas que habían desembarcado en Ancón del navío de Diego de Simancas, quien, como se ha visto, era uno de los grandes armadores del comercio con México. ${ }^{34}$ La coyuntura

\footnotetext{
${ }^{33}$ AGI, Lima 35. Carta del virrey Montesclaros al rey. Callao, 9 de abril de 1608.

${ }^{34}$ AGI, Escribanía de Cámara 503-A. El fiscal y Alonso de San Juan contra Francisco de Palencia Blanco y consortes sobre ciertos caxones de ropa china, 1611-1613.
} 
del mercado peruano se complicaría casi de inmediato. La prohibición del ingreso de productos asiáticos y la pronta aparición del contrabando de estos géneros coincidió con la gran saturación del mercado peruano de los años 1612 y 1613, que sería desastrosa para la Ciudad de Los Reyes, pues quebrarían muchos mercaderes, dos bancos, lo que condujo a que rápidamente se buscaran las causas y los culpables de esta situación.

Casi después de su fundación, el 15 de mayo de 1613, el Consulado de Lima elaboró un memorial en donde expresaban los daños que acarreaba a los comerciantes y al monarca la restricción en el intercambio comercial con México a sólo productos de la tierra, por lo que proponía cerrar la ruta. Según el Tribunal, llevar botijas de vino y de vinagre, y sal para el consumo del puerto de Acapulco -"que tiene 50 vecinos y esta 80 leguas de Mexico de adonde de hordinario van y vienen muchas requas y les proveen de lo necesario" 35 - no tenía ningún sentido. El único fin del comercio con México era la importación de mercancías chinas, pues el tráfico con productos de la tierra era mínimo, de tan sólo algunos paños y "cosas de fierro labrado, tafetanes lisos [...] de lo qual no tiene ninguna necesidad ni recibe beneficio este reyno", ${ }^{36}$ ya que mejores paños se labraban en la provincias de Quito y otras partes. Las sedas mexicanas eran tan malas y caras que sólo las trasladaban a Perú para poder traer subrepticiamente géneros de China. Así, con la nueva regulación, salían 1500000 pesos sin registro alguno, dinero que regresaba empleado en ropa china, la cual igualmente se ocultaba y no pagaba ningún impuesto. Los maestres pasaban por muchos de los puertos abiertos y despoblados de las costas de Perú, por lo que antes de llegar al Callao muchos de estos productos ya habían sido vendidos. De este modo, el rey perdía cada año 500000 ducados de derechos, además de que "es contratación aparte esta de China y tiene sus correspondencias por allá sin dependencia alguna con España”. No sólo se estaba defraudando al monarca, sino que los comerciantes con Castilla estaban "destruidos" por el bajo precio de estos géneros, y debido a esta contratación no podía "digerir este Reyno tan pequeñas flotas como las que vienen a Tierra Firme cada dos años" ${ }^{37}$ Adicionalmente, también se dañaba al reino de Tierra Firme porque, como había disminuido el trato con España, los dueños de naos y recuas ganaban menos. Así, este comercio estaba causando daño general en todos los reinos de España, pues era plata que pasaba a "otros estraños como los de China sin retornar a los de vuestra magestad, que no yendo por este camino avian de yr de España y volver en mercaderías". Para confirmar lo dicho, el Consulado de Lima

\footnotetext{
${ }^{35}$ AGI, Lima 143. Memorial del Consulado de Lima. 15 de mayo de 1613.

${ }^{36}$ AGI, Lima 143. Memorial del Consulado de Lima. 15 de mayo de 1613.

${ }^{37}$ AGI, Lima 143. Memorial del Consulado de Lima. 15 de mayo de 1613.
} 
pedía que se hiciera relación de la plata enviada a la Casa de la Contratación durante los años 1607, 1608 y 1609, y de los almojarifazgos pagados en 1608 y 1610 -en los que estuvo cerrada la contratación con México-, y que se comparase luego con los de 1611 y 1612, en los que hubo navío de permiso, para ver claramente la gran disminución de derechos reales.

El Consulado de Lima calculaba que había tres posibles soluciones. Una, que el monarca liberara el comercio con México de trabas y todas las contrataciones fuesen lícitas, y que hubiese registro abierto de plata; de esta manera, no se eludirían los derechos reales y, al pagar impuestos, los géneros chinos no serían tan apetecibles. La otra, que se redujera el tráfico a un solo navío de 200 toneladas que saliese de Perú con registro "amplio o coactado" cargado de plata a Nueva España, y que pudiese volver con mercaderías de China y se le cobrase impuestos muy altos; de este modo, el empleo sería pequeño y los derechos tan altos y rigurosamente cobrados que, poco a poco, se reduciría el trato. La tercera vía consistía en que se cerrara y prohibiera por completo la contratación entre México y Perú. El inconveniente de la primera solución era que los habitantes de Perú se inclinarían por emplear todos sus caudales en géneros de China "por la mejor y más breve ganancia que tendrían", y con ello cesaría el intercambio comercial con España. La segunda solución acarreaba el problema de que con un solo navío de poco volumen y mucho valor también peligraría el comercio con España, además de que no reduciría el contrabando en los numerosos puertos de Perú. Por ello, el Consulado consideraba que la tercera salida, la del cierre de la ruta mercantil, era la más conveniente, puesto que no había ninguna necesidad real de mantener un intercambio comercial entre ambos virreinatos; después de todo, las mercaderías chinas, aunque baratas, no eran de la calidad y durabilidad de las procedentes de España; y si hubiese alguna necesidad de contacto entre los virreinatos, se podrían despachar navíos pequeños de aviso que viajarían según las necesidades. El tribunal emplazaba, así, a dejar de atender los intereses particulares, como el de los tratantes mexicanos de China, y velar por los de la monarquía y los de todos sus vasallos y reinos. ${ }^{38}$

La Audiencia de Lima, por su parte, tenía una óptica diferente del problema. Su fiscal, el licenciado Blas de Torres Altamirano, sostenía que las quiebras de mercaderes y bancos se debían a la creación del Tribunal del Consulado, que había tratado con suavidad a los miembros del gremio y estaba protegiendo exclusivamente a los que tenían gruesos caudales. ${ }^{39} \mathrm{El}$ Tribunal había "estrechado la contratación" y mucha gente había dejado

\footnotetext{
${ }^{38}$ AGI, Lima 143. Memorial del Consulado de Lima. 15 de mayo de 1613.

${ }^{39}$ AGI, Lima 144. Carta de Blas de Torres Altamirano al rey. Lima, 6 de abril de 1644.
} 
de invertir en el comercio para comprar casas y tierras. ${ }^{40}$ La sala del crimen aseguraba, en 1616, que el Consulado había pedido que no saliesen navíos a México en los últimos tres años, y que el resultado había sido el aumento de los precios, lo que tenía "en daño notable a los compradores" ${ }^{41}$ Por su parte, la respuesta del Consulado se limitaba a decir que las quiebras habían sido ocasionadas por la "esterilidad de los tiempos" y la abundancia de mercaderías prohibidas que venían por Nueva España y otras partes, consentidas "por algunos ministros por sus intereses". Además, el Tribunal le recordaba al monarca la importancia de cerrar por completo el tráfico con México "por la poca necesidad de los frutos de aquel en este", y le pedía su prohibición. ${ }^{42}$

El Consulado mantuvo su postura durante los años subsiguientes. En 1616 se entabló un juicio a Gaspar de la Fuente -dueño y maestre de la fragata Santa Margarita- y a varios otros, por haber enviado sin licencia del gobierno el navío a México el año anterior de 1615. La embarcación había salido del Callao so pretexto de ir a los valles por trigo, carbón y otros productos (específicamente a los puertos de Pisco y Perico), pero el Consulado de Lima había advertido que llevaba gran cantidad de plata para comprar mercancías asiáticas. El fiscal de la Audiencia, el licenciado Cacho de Santillana, afirmaba que la audacia y atrevimiento de algunos mercaderes había sido tal que en los últimos años se había traído una gran cantidad de géneros chinos, en perjuicio del comercio de Lima y de España. Los contrabandistas -decía el fiscal-innovaban sus estrategias; el 1 de febrero de 1615 se enteró de que el día anterior habían salido cuatro naves, hacia Pisco, hacia Huaura y otras hacia Huambacho, las cuales llevaban plata para contratar en México. El navío Santa Margarita, por ejemplo, había salido a pesar del pedido expreso del Consulado de que no se le otorgara licencia para el viaje; lo pilotaba Juan de la Cueva Pacheco, experto en la ruta, que fue apresado por el fiscal a su retorno. La sorpresa es que uno de los líderes de la operación había sido Bartolomé González, cónsul de tribunal, quien se había encargado de financiar a los que se embarcaron. ${ }^{43}$

Los miembros de la Audiencia hicieron un interrogatorio y llamaron a los notarios que habían asentado las escrituras de entrega de plata: el cónsul y Jerónimo López de Saavedra -quien sería luego depositario general

${ }^{40}$ AGI, Lima 144. Parecer de Gaspar de Lesquina. Lima, 7 de octubre de 1614.

${ }^{41}$ AGI, Lima 144. Carta de la Sala del Crimen al rey. Lima, 20 de mayo de 1616.

${ }^{42}$ AGI, Lima 144. Memorial del Consulado de Lima al rey. Lima, 8 de abril de 1614. Carta del Consulado al rey. Lima, 8 de abril de 1614. El Cabildo, en 1626, declaró que las quiebras habían sido causadas por la pérdida de tres galeones entre Cartagena y La Habana en 1605, el naufragio del navío de Diego de Simancas en Nueva España en 1610 y la abundancia de ropa de México y España en el mercado. AGI, Lima 144. Carta del Cabildo de Lima al rey. Lima, 18 de mayo de 1626.

${ }^{43}$ AGI, Escribanía de Cámara 503 B. 
de la ciudad- terminaron presos. Ante las presiones, el mercader Juan de Urrutia habló en nombre de los factores que viajaban a México. Explicó que la motivación del Consulado de impedir la salida había sido el desastre causado por los peruleros, quienes habían vuelto de Portobelo con plata, pues la mayor parte de la contratación había sido fiada a malos precios, y se habían visto obligados a hacer baratas. Añadía que los limeños tenían deudas por pagar en México, razón por la que se habían embarcado. ${ }^{44}$

Dentro del contencioso existe un largo memorial del Consulado que recoge las razones de papeles previos, pero agrega nuevas justificaciones para no cargar plata y mercaderías a México. Según este documento, en diciembre de 1604 el rey ordenó por cédula que el comercio entre Perú y México consistiera solamente de productos de la tierra, de tal manera que sólo se pudieran llevar algunas botijas de vino y vinagre, lana y sal para los 50 vecinos que habitaban Acapulco, y se trajeron unos cuantos frutos de poca monta al retorno. Por esta razón, en 1609 se permitió que saliesen cada año de Perú navíos de registro con 200000 ducados en plata para emplear en todo el reino de Nueva España. Pero -decía el ConsuladoMéxico no tenía ningún fruto para ofrecer a Perú, y los que había eran de tan mala calidad que, en realidad, no habría ninguna necesidad de comerciar con Nueva España. ${ }^{45}$ Así, este tráfico sólo tenía sentido por los productos chinos. ${ }^{46}$ Los mexicanos estaban autorizados de enviar a China 500000 ducados, pero traían tal cantidad de géneros que reexportaban a España 1500 000, además de 1500000 adicional que se embarcaba hacia Perú. En el virreinato peruano, este comercio había distorsionado el mercado, muchos comerciantes habían quebrado y dos bancos, el de Juan Vidal y el de Diego de Morales, habían sido arrastrados. La ciudad se encontraba en estado deplorable: las exportaciones de plata destinadas a México y España la dejaban sin un real, estaba plagada de bandas de mendigos que pedían limosna, los hospitales y obras pías no recibían contribuciones, las tiendas estaban vacías y el bullicio de la calle de los mercaderes había cesado. El documento del Consulado culminaba con una reflexión política: si de Portugal, Aragón, Valencia y Cataluña no se podía sacar plata para el erario castellano (siendo el rey cabeza de todos los reinos) para evitar el debilitamiento de estos, ¿̇por qué Perú tenía que empobrecerse para "engrosar a México o más propiamente a la China", que ni siquiera estaba bajo el orbe del monarca? Firmaban el memorial el prior y los cónsules

${ }^{44}$ AGI, Escribanía de Cámara 503 B.

${ }^{45}$ AGI, Escribanía de Cámara 503 B.

${ }^{46} \mathrm{Ni}$ siquiera eran ya apetecibles los productos europeos, como en el siglo XVI. En 1622, por ejemplo, Francisco Ramírez de los Olivos demandó a Gonzalo Sánchez de Herrera, vecino de México, porque le vendió a su factor, Diego del Peso, mercaderías de Castilla en lugar de géneros chinos. AGI Escribanía de Cámara 505 A. 
del Tribunal, entre los que se encontraba Bartolomé González, aquel que había sido apresado por financiar el cargamento a México. ${ }^{47}$

Estos argumentos podrían resultar convincentes en apariencia, pero en realidad fueron el resultado de los intentos del Consulado por controlar un comercio que por momentos se les escapaba de las manos y que podía generar peligrosas saturaciones del mercado peruano e incluso de otros. En 1602, por ejemplo, don Jerónimo de Guazo informaba al Consulado de Sevilla que cada año entraban a Cartagena de Indias dos o tres navíos de registro desde México cargados de ropa de China, y que cuando llegaban los mercaderes locales se encontraban con que no podían cumplir con sus obligaciones, de manera que el comercio en Tierra Firme se estaba viendo afectado no sólo por el Pacífico, sino también por el Caribe. ${ }^{48}$ Esto, por supuesto, generó una férrea oposición al comercio asiático en Sevilla. Cuando en 1619 el Consulado de México escribió a la Casa de la Contratación pidiendo el cese de las restricciones comerciales con Perú, esta respondió que eso significaría la total destrucción de España, que "es el corazón de este cuerpo y si se sangra quitándole la gente y el trato [...] sin duda vendrá a enfermar o a morir el cuerpo desta monarquía”. ${ }^{49} \mathrm{La}$ Casa no dudaba de que el cierre completo del tráfico con Filipinas desde América y la apertura de una ruta directa por el Cabo de Buena Esperanza ayudarían a conservar "reynos tan apartados [...] [para] que aquellos tengan necesidad destos porque si no la tuviesen presto se les lebantarian los pensamientos [...] y perjudiciales imaginaciones". Además, subrayaba que había que tener mucho cuidado con esta situación, pues al haberse dado licencia para plantar viñas y construir obrajes en Perú y Nueva España, el tráfico español de vino con América había cesado y ya era muy poco lo que se llevaba de textiles. En consecuencia, permitir el libre comercio entre ambos virreinatos significaría el fin del comercio con España. ${ }^{50}$

En mayo de 1631, el Consulado de Lima presentó un último memorial al monarca, pero esta vez solicitaba, esgrimiendo nuevas consideraciones, una rectificación de la prohibición de tratar con mercaderías asiáticas en la ruta novohispana. Sin duda, este cambio de postura se debió al ascenso de Juan de Urrutia a prior del Tribunal, quien -como se ha visto- traficaba en esta ruta y era uno de los agentes más importantes de los comerciantes novohispanos. En este documento, el Consulado repetía la idea de que el

\footnotetext{
${ }^{47}$ AGI, Escribanía de Cámara 503 B.

${ }^{48}$ AGI, Consulados 313. Carta de don Jerónimo de Guazo al Consulado. Cartagena, 16 de agosto de 1602 .

${ }^{49}$ Carta de la Casa de la Contratación al rey. Sevilla, 24 de octubre de 1619, fs. 293v-294r. Contratación 5172. AGI.

${ }^{50}$ AGI, Contratación 5172. Carta de la Casa de la Contratación al rey. Sevilla, 24 de octubre de 1619 , fols. 293v-294r.
} 
tráfico tal y como estaba regulado, era mejor cerrarlo por completo. Sin embargo, se inclinaba por la apertura comercial de los géneros orientales y que los comerciantes pudiesen enviar 200000 ducados a Nueva España para este efecto. ${ }^{51}$ Según el Tribunal, todas las prohibiciones eran "odiosas y en grave daño de los vasallos", por lo que censurar el comercio asiático acarreaba varios perjuicios. En primer lugar, al limitarse el intercambio a productos de la tierra y estando la ciudad de México inundada, los mercaderes de Perú no encontraban ni mercaderes ni mercaderías, y se pasaban dos o tres años buscando qué comprar, mientras que antes, cuando se adquirían bienes asiáticos, los viajes duraban tan sólo diez meses. En segundo lugar, las mercancías asiáticas habían subido de precio desde la prohibición, y esta alza afectaba a los más pobres de la ciudad de Lima. En tercer lugar, consideraba que la medida no era equitativa: si se permitía llevar estos géneros a Castilla y a todas las islas de Barlovento, "parece injusticia" que sólo se prohibiese llevarlas a Perú, en donde había tanta necesidad de los textiles asiáticos por la naturaleza del clima. El cuarto problema, señalaba el Consulado, era que los mercaderes estaban recibiendo maltratos de los oficiales reales cada vez que se anunciaba la llegada de un navío de México, y eran acosados por "vandadas de gente perdida" que buscaban las mercaderías prohibidas en sus navíos como si fuesen enemigos que podían desvalijar. Un quinto daño detectaba el Tribunal: aquel que tenía que ver con los efectos de la demanda americana sobre los vasallos de Castilla. Si el Perú comprara menos productos castellanos, estos bajarían de precio, para beneficio de los compradores del reino peninsular. Después de todo -afirmaba- sólo se traficarían 200000 ducados de géneros chinos, mientras que a España se llevaban 4000000 o 5000 000. Adicionalmente, si se permitiese el comercio asiático, el rey se beneficiaría de la concesión, puesto que las mercaderías ya pagarían impuestos. Finalmente, declaraba que sólo quedarían dudas acerca de si el comercio de Sevilla y Tierra Firme se vería afectado; pero al restringirse el tráfico a 200000 ducados esta observación quedaría resuelta. ${ }^{52}$

El Consulado de Lima fue muy cauteloso y no mencionó en estos memoriales a los funcionarios como algunos de los actores más problemáticos de este comercio, posiblemente con el fin de no interrumpir las negociaciones políticas con las máximas autoridades virreinales que debían elevar la presión fiscal a solicitud de la corte madrileña. ${ }^{53}$ Pero, ciertamente, oficiales reales, gobernadores e incluso los virreyes hacían de las suyas en

\footnotetext{
${ }^{51}$ AGI, Lima 107. Carta del Consulado de Lima al rey. Lima, 30 de mayo de 1631.

${ }^{52}$ AGI, Lima 107. Carta del Consulado de Lima al rey. Lima, 30 de mayo de 1631, se adjunta memorial.

${ }^{53}$ Sobre las negociaciones fiscales del virrey conde de Chinchón con la elite peruana véase Amadori, 2013, cap. IV.
} 
México, Manila y Perú. Como ya se ha mencionado, era frecuente en Acapulco que los oficiales reales obligaran a vender o fletar forzosamente los navíos peruanos a la Real Hacienda mexicana para embarcarlos rumbo a Manila, a cambio de otorgarles permiso para comerciar directamente en las islas. Como mucha plata iba "en confianza", los sobornos a los oficiales eran parte del funcionamiento de este tráfico, del que también participaban los funcionarios manileños, puesto que era su forma de sobrevivir. ${ }^{54}$ En Perú, esta situación no podía ser peor, pues los virreyes intervenían directamente en el entramado de este comercio. Era frecuente que se ofreciesen a enviar navíos de permiso a México si los comerciantes accedían a prestar plata a la Real Hacienda para engrosar las remesas a la monarquía. ${ }^{55}$ Según un informe de los oficiales reales, hasta 1615 los barcos que navegaban a 60 leguas a la redonda de Lima sólo requerían del permiso de los oficiales reales. No obstante, ese mismo año, el virrey marqués de Montesclaros lo modificó y obligó a que todos pasasen por Palacio para sacar licencia, bajo el argumento de que los navíos se embarcaban, en realidad, hacia México ${ }^{56}$ Como se puede sospechar, esta decisión no estaba dirigida a encaminar la política comercial, sino que fue una manera de obtener granjerías. Otro informe de los mismos oficiales sostenía que en el Callao los virreyes colocaban a sus criados en los cargos de general del puerto y, de esta manera, por ser "echuras de los virreyes", pasaban todos los fardos que pertenecían a sus casas de contrabando, muchos de los cuales procedían de Nueva España. De igual manera, nombraban para este efecto a sus criados maestres y contramaestres. ${ }^{57}$ Incluso estos funcionarios acusaron solapadamente al virrey príncipe de Esquilache de conceder la recolección de almojarifazgos al Consulado con el fin de que pudiesen realizar sus operaciones fraudulentas sin control, de tal manera que el reino se iba a "henchir" de mercaderías chinas. ${ }^{58}$

Pero tal vez la acusación más grave la hizo fray Roque de Saona en un memorial al rey, suscrito en 1634 . El fraile denunciaba que el virrey conde de Chinchón obtenía entre 12000 y 13000 pesos de los navíos de permiso que navegaban a México o a Nicaragua, y los obligaba a traer brea, que era ingresada a los almacenes reales a precios muy elevados. Jorge Rodríguez de Lisboa, mercader riquísimo, pagó 14000 pesos para viajar a México, al igual que Simón Cascos de Quirós, quien desembolsó 12000 pesos para lo mismo; luego ingresaron por "los jardines de palacio que cae al puente" 70 cajas de ropa prohibida de China. Asimismo, el banquero Juan

\footnotetext{
${ }^{54}$ AGNP, Real Tribunal del Consulado, judicial, caja 145-2, año 1614.

${ }^{55}$ AGI, Lima 113. Carta de los oficiales reales al rey. Lima, 25 de abril de 1611.

${ }^{56}$ AGI, Lima 114. Carta de los oficiales reales al rey. Lima, 12 de junio de 1632.

${ }^{57}$ AGI, Lima 113. Carta de los oficiales reales al rey. Lima, 27 de abril de 1619.

${ }^{58}$ AGI, Lima 113. Carta de los oficiales reales al rey. Lima, 15 de abril de 1621.
} 
de la Cueva le prestó 50000 pesos para que su hermano Esteban los llevase a emplear a México en ropa de contrabando y "prohibida de la China" en 1629 , y por no haber regresado a tiempo "obligó con violencia y con mano poderosa le pagase cada un año de su detención ochenta por ciento y esto es público y notorio". En una anotación al margen del mismo documento, se lee que el banquero, para evitar la eventualidad de una quiebra por estas demandas tan exorbitantes, le pidió al virrey que mandase a su banco la plata que solía manejar el depositario general. Este aceptó e hizo quebrar al depositario general, y desde entonces ingresaron al banco más de 250000 pesos por este concepto, de los cuales 50000 pesos pagaban la deuda del virrey, más los intereses, que ascendían a $90000 .^{59}$

$\mathrm{Si}$ estas informaciones son ciertas, no cabe duda de que semejante interferencia del máximo gobernante de Perú incrementó aún más los contratiempos ya existentes en esta ruta. Como se ha explicado anteriormente, debido a que los comerciantes y los navíos peruanos fueron detenidos en Nueva España en 1629, no es de extrañar que, luego de este descalabro, tanto el virrey como los comerciantes se negasen a despachar navíos a México los años subsiguientes, a pesar del intento de la facción comercial de Urrutia de reabrir la ruta en 1631. De hecho, en 1633 se canceló el navío de permiso con la aprobación del Consulado y de los 50 comerciantes más ricos de Lima (Rodríguez, 1960, p. 246.), y finalmente la corona decidió actuar prohibiendo el comercio en 1634. Ciertamente, la negativa a enviar navíos de permiso por parte del Consulado no se debió exclusivamente a los problemas intrínsecos de la ruta, sino que fueron varios elementos los que confluyeron para hacer de esta década una de las más críticas de la historia del comercio virreinal peruano. Además de los contratiempos del navío de permiso a México, la minería potosina aún no se había recuperado de los efectos negativos de la guerra entre vicuñas y vascongados, ni de los conflictos por el suministro de azogue; en la ruta atlántica, en la que los peruleros habían obtenido sustanciales beneficios, el monarca confiscó en 1629 las remesas de los peruanos en Sevilla; en 1633 quebró el depositario general, y el banco público más importante -el de Juan de la Cueva- se contrajo desde 1632 y fue a la bancarrota en 1635, con un monto equivalente a $65 \%$ de la remesas peruanas al monarca; y un año después, se realizó el secuestro más grande de bienes de judíos portugueses por parte del Santo Oficio, la mayoría de los cuales se dedicaba al comercio (véase Suárez, 2001, pp. 77 y ss.). Fue tal el marasmo que difícilmente los grandes hombres de negocios se hallaron dispuestos a hacer concesiones en los

${ }^{59}$ AGI, Lima 173. Memorial. Apuntamientos en los que se deben advertir y considerar en razón del gobierno del conde de Chinchón virrey del Piru. Por fray Roque de Saona. Lima, 20 de mayo de 1634 . 
siguientes años. Así, cuando el Cabildo de la capital -sea para permitir el ingreso de mercaderías chinas con el fin de satisfacer el boato en la vestimenta de los vecinos, sea para permitir el tráfico a pequeña escala de sus regidores- pidió repetidas veces que se reabriese el tráfico para evitar las "bandadas" de perdición que habían llegado de México y para aliviar a los vasallos más pobres, las autoridades y los mercaderes no cedieron. ${ }^{60}$

En México, por su parte, los comerciantes se vieron seriamente perjudicados por la abrupta ruptura del flujo de plata peruana. Tan importante era que en 1616, por ejemplo, le escribieron al Consulado de Sevilla que las mercaderías estaban más baratas en México que en España, pero esperaban que la situación mejorase con el arribo de los navíos procedentes de Perú. En 1622 se dirigieron a sus colegas sevillanos para decirles que el comercio mexicano con España se estaba perdiendo por la caída de la contratación con el virreinato andino. ${ }^{61} \mathrm{Y}$ en 1637 le expresaron claramente al Consulado de Sevilla que eran ellos los que habían obtenido la cédula del rey que prohibía el comercio entre México y Perú, pensando que esto aumentaría el comercio sevillano; pero -decía el Tribunal novohispano-si no se permite este tráfico, no podrán esperar que aumenten las exportaciones mexicanas, pues no había consumo en la tierra "por estar cerradas las puertas y navegaciones" y las minas no rendían como antes. ${ }^{62}$

Años después, en 1646, ante la insinuación de reabrir el tráfico, el Consulado de Sevilla sentenciaba: "La verdad es que donde los damascos y demás sedas de aquel reino [de China] se descubren, se inclinan, aficionan, abrevian y facilitan los empleos", si no pregunten a los que sacan plata de Perú para el Realejo y otras partes. ${ }^{63} \mathrm{Y}$ es que, si bien el tráfico con México se cerró, Lima, ya recuperada del hundimiento de la década de 1630, siguió manteniendo una fluida navegación con Panamá, Guatemala, y "las otras costas" -lo que explica que el numerario en Centroamérica fuera perulero en el siglo XVII- (MacLeod, 1973, caps. 14 y 15), de manera que continuaron llegando géneros asiáticos al territorio andino por esta vía. Del mismo modo, como era preciso mover a funcionarios y exportar azogue peruano a México, los mercaderes de Lima mantuvieron activa esta ruta, aunque esta vez eran ellos, y no los mercaderes novohispanos, los que controlaban los tiempos comerciales. Esta conexión "oficial”, previsiblemente,

\footnotetext{
${ }^{60}$ AGI, Lima 109. Carta del Cabildo al rey. Lima, 30 de mayo de 1638; Carta del Cabildo al rey. Lima, 5 de marzo de 1643; Carta del Cabildo al rey. Lima, s. f.

${ }^{61}$ AGI, Consulados 313. Carta del Consulado de México al de Sevilla. México, 30 de octubre de 1616; Carta del Consulado de México al de Sevilla. México, 26 de octubre de 1622; Carta del Consulado de México al de Sevilla. México, 1 de junio de 1622.

${ }^{62}$ AGI, Consulados 313. Carta del Consulado de México al de Sevilla. México, 22 de julio de 1637.

${ }^{63}$ AGI, Consulados 85 A. Carta del Consulado de Sevilla al rey. Sevilla, 1 de febrero de 1646.
} 
fue una pequeña ventana que permitió no sólo que los mercaderes de Lima siguieran introduciendo mercaderías orientales -aunque no necesitaban de esta vía oficial-, sino que algunos virreyes y sus respectivos criados incursionaran en este contrabando. Por esta razón, cuando el Consulado de Lima firmó los asientos de avería del Mar del Norte y del Mar del Sur en 1662 -que hacía recaer en el comercio de Lima 44\% del mantenimiento de la flota atlántica y el total de aquella que navegaba por el Pacifico andino-, los peruleros se opusieron frontalmente a la interferencia de estos funcionarios, como lo demuestra la persecución que hicieran al virrey conde de Castellar (1674-1678) y que terminó con su destitución (sobre el conflicto entre el Consulado y el virrey conde de Castellar véase Suárez, 2012). Esta oposición a la apertura formal del comercio con México mientras se mantuviese el régimen de asientos se expresó reiteradamente, como cuando, en 1725, presentaron ante la corte un "memorial informativo" a través de su agente, Dionisio de Alcedo y Herrera, en el cual se calificaba al contrabando de géneros asiáticos como uno de los principales obstáculos para el cumplimiento de los asientos con el monarca y una de las causas del decaimiento del comercio peruano. ${ }^{64}$ Así, en tanto el monarca tuviese maniatado al Consulado de Lima con los asientos de avería, el Tribunal se opondría a la reanudación del tráfico legal entre Perú y México.

\section{CONCLUSIÓN}

Se podría afirmar que el tráfico asiático trajo consigo tanto grandes ganancias como también grandes problemas. A pesar de las reiteradas restricciones impuestas a este eje comercial, en la documentación notarial revisada de los años 1612 y 1629 -periodo en que zarparon navíos de permiso desde Lima con destino al territorio novohispano- se puede observar que existía un tráfico de géneros asiáticos bien establecido entre Perú y Nueva España, que los grandes cargadores de Lima que participaban en el comercio atlántico -cuyos factores eran conocidos como los "peruleros"invertían en esta ruta, que los comerciantes mexicanos tenían una activa presencia en el mercado limeño, y que se había tejido una red comercial y financiera que unía las ciudades de Lima y México a través de agentes de confianza en ambas capitales. Asimismo, estas fuentes revelan que el puerto de Acapulco no funcionaba aún como un centro ferial, sino que

\footnotetext{
${ }^{64}$ AGI, Lima 519, "Memorial informativo que pusieron en sus reales manos del rey nuestro señor (que Dios guarde) el Tribunal del Consulado de la ciudad de los Reyes y la junta general del comercio de las provincias del Peru", por don Dionisio de Alcedo y Herrera, año 1725, fs. 119 y ss.
} 
todas las transacciones se realizaban directamente en la ciudad de México o, en su defecto, en Manila.

Ambas fechas marcaron virajes en la postura del Tribunal del Consulado de Lima ante este tráfico. En 1613 se produjo la primera gran saturación del mercado peruano que arrastró consigo a muchos mercaderes y a dos bancos públicos de la ciudad. El Consulado atribuyó esta crisis a los efectos negativos del comercio con México, pues consideraba que saturaba el mercado peruano y desviaba peligrosamente capitales al virreinato del norte y a China. De esta manera, en los años posteriores, el gremio mercantil intentó medir la llegada de géneros asiáticos con el fin de evitar nuevas quiebras, a pesar de que algunos interesados en el eje asiático y, sobre todo, los representantes de los comerciantes novohispanos, declararon que los desequilibrios en el mercado se debían a los malos cálculos de los peruleros en el tráfico atlántico. Pero el punto de quiebre fue el navío de 1629 que, según fuentes oficiosas, cargó mucha plata subrepticiamente. Los oficiales mexicanos secuestraron las dos embarcaciones peruanas que se hallaban en Acapulco para enviarlas a Manila y, en consecuencia, los empleos no se pudieron efectuar y los factores llegaron a Lima años después. Esta intervención causó serios efectos en el comercio peruano, debido a que se incumplieron las obligaciones contraídas, e incluso los negocios del virrey de Perú resultaron afectados. Para empeorar el panorama, esto coincidió con dificultades en la minería potosina, problemas en la ruta atlántica y con la contracción de las entidades financieras limeñas. En consecuencia, y con el apoyo de la máxima autoridad gubernamental, el Tribunal se negó a despachar en adelante navíos a Nueva España, hasta que llegó la cédula de 1634 que prohibía el comercio entre Perú y México.

De este modo, el atractivo negocio de géneros asiáticos trajo consigo una serie de complicaciones: saturaciones del mercado peruano, interferencia de los comerciantes mexicanos, e intromisión de los funcionarios del gobierno en Lima y en Nueva España. Por ello, los peruleros, que ya estaban desplegando con éxito estrategias para sacar provecho en la ruta atlántica, no se opusieron a su cierre, puesto que la prohibición les permitía medir la llegada de mercaderías asiáticas y colocar en sus manos el control del comercio interdicto, ya que ellos seguirían navegando a Tierra Firme, Guatemala y México en lo que restaba del siglo. Si bien los mercaderes mexicanos y los vecinos más pobres de Lima protestaron amargamente por el cierre, el veto se mantuvo, excepto para el traslado de mercurio peruano y de funcionarios. Existen rastros de esta aventura. Junto a cuadros de Sevilla, pinturas cuzqueñas y piedras traídas de Ámsterdam, las habitaciones de las casas limeñas se decoraban con escritorios-contadores y porcelanas chinas, y hasta con sobrecamas de la India. En las fiestas públicas, los vecinos de Lima adornaban sus balcones con mantones de Manila, que procedían, en reali- 
dad, de China. Pero la ruta de las sedas, rasos y damascos que unía a Lima con Asia continuó siendo un circuito prohibido que no se abriría mientras se mantuviesen el régimen de galeones y los asientos que lo sustentaban.

\section{LISTA DE REFERENCIAS}

Alonso, L. (2009). El costo del imperio asiático. La formación colonial de las islas Filipinas bajo dominio español, 1565-1800. México: Instituto de Investigaciones Dr. José María Luis Mora/Universidade da Coruña.

AMADORI, A. (2013). Negociando la obediencia. Gestión y reforma de los virreinatos americanos en tiempos del conde-duque de Olivares (1621-1643). Madrid: Consejo Superior de Investigaciones Científicas/Universidad de Sevilla/Diputación de Sevilla.

Barrantes, V. (2004). Guerras piráticas de Filipinas (1570-1806). Málaga: Algazara.

Bernal, A. M. (1992). La financiación de la Carrera de Indias (1492-1824). Dinero y crédito en el comercio colonial español con América. Sevilla: Fundación El Monte.

Bonialian, M. (2012). El Pacífico hispanoamericano política y comercio asiático en el imperio español (1680-1784). México: El Colegio de México.

Chaunu, P. y H. (1955-1959). Seville et L'Atlantique, 1504-1650. 8 vols. París: SEvPen.

Cruikshank, B. (2006). Directory of Manila galleon voyages, 1565 through 1815. Recuperado de http://home.windstream.net/cr33856/

EsCALONA, G. DE (1775). Gazophilacium regium perubicum (lib. II, part. II, cap. XI, p. 179). Madrid: Imprenta Blasil Roman.

Flores, R. (2005). El secreto encanto de Oriente. Comerciantes peruanos en la ruta transpacífica (1590-1610). En S. O'Phelan y C. Salazar-Soler (eds.), Passeurs, mediadores culturales y agentes de la primera globalización en el Mundo Ibérico, siglos XVIXIX (pp. 377-409). Lima: Pontificia Universidad Católica del Perú/Instituto RivaAgüero/Instituto Francés de Estudios Andinos.

GARCíA, L. (1997). Los peruleros y el comercio de Sevilla con las Indias, 1580-1630. Sevilla: Universidad de Sevilla.

GARCíA, M. F. (1992). Una propuesta de reestructuración del Imperio español en el siglo XVII. REVISTA “A”, 29, 24-32.

García, M. F. (1996). Forzados y reclutas. Los criollos novohispanos en Asia (1756-1808). México: Potrerillos Editores.

IWASAKI, F. (2005). Extremo Oriente y el Perú en el siglo XVI. Lima: Pontificia Universidad Católica del Perú.

LATASA, P. (1997). Administración virreinal en el Perú: gobierno del marqués de Montesclaros (1607-1615). Madrid: Editorial Centro de Estudios Ramón Areces.

Latasa, P. y Fariñas, M. (1991). El comercio triangular entre Filipinas, México y Perú a comienzos del siglo XVII. Revista de Historia Naval, 9(35), 13-35.

Lynch, J. (1993). Los Austrias (1598-1700). Barcelona: Crítica. 
MacLeod, M. (1973). Spanish Central America. A socioeconomic history, 1520-1720. Berkeley: University of California Press.

Rodríguez, M. E. (1960). El Tribunal del Consulado de Lima en la primera mitad del siglo XVII. Madrid: Ediciones Cultura Hispánica.

SuArdo, J. A. (1936). Diario de Lima (1629-1639), 2 vols. Lima: Imprenta de Carlo E. Vásquez.

SuÁREZ, M. (diciembre, 1993). Monopolio, comercio directo y fraude: la élite mercantil de Lima en la primera mitad del siglo XVII. Revista Andina, 22, 487-502.

SuÁrez, M. (1995). Comercio y fraude en el Perú colonial. Lima: Instituto de Estudios Peruanos/Banco Central de Reserva.

SuÁrez, M. (2001). Desafíos transatlánticos. Mercaderes, banqueros y el estado en el Perú virreinal, 1600-1700. Lima: Instituto Riva-Agüero/Pontificia Universidad Católica del Perú/Fondo de Cultura Económica.

SuÁrEz, M. (2012). Galeones, mercaderes y virreyes: tensiones en el imperio hispánico en la segunda mitad del siglo XVII. En E. VILA y J. LACUEVA (coords.), Mirando las dos orillas. Intercambios económicos, sociales y culturales entre Andalucía y América (pp. 165-182). Sevilla: Fundación Buenas Letras.

Subrahmanyam, S. (2005). As quarto partes vistas das Molucas: Brece re-leitura de Antonio Galvão. En S. O'Phelan y C. Salazar-Soler (eds.), Passeurs, mediadores culturales y agentes de la primera globalización en el Mundo Ibérico, siglos XVI-XIX (pp. 713-730). Lima: Pontificia Universidad Católica del Perú/Instituto Riva-Agüero/ Instituto Francés de Estudios Andinos.

VALle, G. DEL (2005). Los mercaderes de México y la transgresión de los límites al comercio pacífico en Nueva España, 1550-1620. Revista de Historia Económica. Journal of Iberian and Latin American Economic History, 23(1), 213-240.

Veitia, J. (1945). Norte de la contratación de las Indias occidentales. Buenos Aires: Comisión Argentina de Fomento Interamericano.

VILA, E. (1984). Las ferias de Portobelo. Apariencia y realidad del comercio con Indias. Anuario de Estudios Americanos, 39, 275-340.

Yuste, C. (2013). De la libre contratación a las restricciones de la permisión. La andadura de los comerciantes de México en los giros iniciales con Manila, 1580-1610. En S. Bernabéu y C. MARTínez (eds.), Un océano de seda y plata: el universo económico del Galeón de Manila (pp. 85-106). Sevilla: Consejo Superior de Investigaciones Científicas.

\section{OTRAS FUENTES}

\section{Archivos}

AGNP Archivo General de la Nación, Lima, Perú.

AGI Archivo General de Indias, Sevilla, España. 